\title{
Physostigmine and Galanthamine Bind in the Presence of Agonist at the Canonical and Noncanonical Subunit Interfaces of a Nicotinic Acetylcholine Receptor
}

\author{
Ayman K. Hamouda, ${ }^{1}$ Tilia Kimm, ${ }^{1,2}$ and Jonathan B. Cohen ${ }^{1}$ \\ 'Department of Neurobiology and ${ }^{2} \mathrm{PhD}$ Program in Neuroscience, Harvard Medical School, Boston, Massachusetts 02115
}

Galanthamine and physostigmine are clinically used cholinomimetics that both inhibit acetylcholinesterase and also interact directly with and potentiate nAChRs. As with most nAChR-positive allosteric modulators, the location and number of their binding site(s) within nAChRs are unknown. In this study, we use the intrinsic photoreactivities of $\left[{ }^{3} \mathrm{H}\right]$ physostigmine and $\left[{ }^{3} \mathrm{H}\right]$ galanthamine upon irradiation at $312 \mathrm{~nm}$ to directly identify amino acids contributing to their binding sites in the Torpedo californica nAChR. Protein sequencing of fragments isolated from proteolytic digests of $\left[{ }^{3} \mathrm{H}\right]$ physostigmine- or $\left[{ }^{3} \mathrm{H}\right]$ galanthamine-photolabeled $\mathrm{nAChR}$ establish that, in the presence of agonist (carbamylcholine), both drugs photolabeled amino acids on the complementary (non- $\alpha$ ) surface of the transmitter binding sites $(\gamma \mathrm{Tyr}-111 / \gamma \mathrm{Tyr}-117 / \delta \mathrm{Tyr} 172)$. They also photolabeled $\delta \mathrm{Tyr}-212$ at the $\delta-\beta$ subunit interface and $\gamma \mathrm{Tyr}-105$ in the vestibule of the ion channel, with photolabeling of both residues enhanced in the presence of agonist. Furthermore, $\left[{ }^{3} \mathrm{H}\right]$ physostigmine photolabeling of $\gamma \mathrm{Tyr}-111, \gamma \mathrm{Tyr}-117, \delta \mathrm{Tyr}-212$, and $\gamma \mathrm{Tyr}-105$ was inhibited in the presence of nonradioactive galanthamine. The locations of the photolabeled amino acids in the nAChR structure and the results of computational docking studies provide evidence that, in the presence of agonist, physostigmine and galanthamine bind to at least three distinct sites in the nAChR extracellular domain: at the $\alpha$ - $\gamma$ interface (1) in the entry to the transmitter binding site and (2) in the vestibule of the ion channel near the level of the transmitter binding site, and at the $\delta$ - $\beta$ interface (3) in a location equivalent to the benzodiazepine binding site in $\mathrm{GABA}_{\mathrm{A}}$ receptors.

\section{Introduction}

The development of drugs that enhance brain nAChR function represents an important approach for the treatment of many cognitive and neurodegenerative disorders (Faghih et al., 2008; Taly et al., 2009; Williams et al., 2011). The ability of physostigmine and galanthamine to improve cognitive functions in a subset of Alzheimer's patients (van Dyck et al., 2000; Cummings, 2004) was originally attributed to their inhibition of acetylcholinesterase, but it is now recognized that direct interactions with brain nAChRs may also contribute to their efficacy (Maelicke and Albuquerque, 2000; Wilkinson et al., 2004; Geerts et al., 2005). Physostigmine and galanthamine potentiate agonist-induced responses and, in the absence of agonist, directly activate nAChRs by binding to site(s) apparently distinct from the transmitter binding sites (Pereira et al., 1993, 1994; Samochocki et al., 2003; Akk and Steinbach, 2005; Militante et al., 2008). Since the introduction of physostigmine, other structurally unrelated drugs have been identified as nAChR-positive allosteric modulators,

\footnotetext{
Received July 20, 2012; revised Nov. 7, 2012; accepted Nov. 12, 2012.

Author contributions: A.K.H. and J.B.C. designed research; A.K.H. and T.K. performed research; A.K.H. and J.B.C. analyzed data; A.K.H. and J.B.C. wrote the paper.

This work was supported in part by the Edward and Anne Lefler Center of Harvard Medical School and U.S. Public Health Services Grant GM58448. We thank Drs. David Chiara and Selwyn Jayakar for useful comments on this manuscript.

Correspondence should be addressed to Dr. Jonathan B. Cohen, Department of Neurobiology, Harvard Medical School, 220 Longwood Avenue, Boston, MA 02115. E-mail: Jonathan_Cohen@hms.harvard.edu.

DOI:10.1523/JNEUROSCI.3483-12.2013

Copyright $\odot 2013$ the authors $\quad 0270-6474 / 13 / 330485-10 \$ 15.00 / 0$
}

which suggests the presence of more than one class of nAChR positive allosteric modulator binding sites (Bertrand and Gopalakrishnan, 2007; Arias, 2010; Williams et al., 2011). Mutational analyses provided evidence for binding sites in the $\alpha 7$ nAChR transmembrane domain for PNU-120596 (Young et al., 2008; daCosta et al., 2011) and in the extracellular domain for galanthamine at the "canonical" subunit interfaces (those containing the transmitter binding sites) (Ludwig et al., 2010), whereas mutations in the $\alpha 3 \beta 2 \mathrm{nAChR}$ predicted a binding site for morantel at "noncanonical" subunit interfaces (Seo et al., 2009).

In this report, we use the intrinsic photoreactivities of physostigmine and galanthamine and protein microsequencing to identify their binding site(s) in the muscle-type Torpedo nAChR. Photoaffinity labeling has been used to identify amino acids in the Torpedo nAChR transmitter binding sites (Mourot et al., 2006) and in binding sites for positive and negative allosteric modulators (Nirthanan et al., 2008; Hamouda et al., 2011). Unlike mutational analyses, photoaffinity labeling allows direct identification of residues in a drug binding site (Vodovozova, 2007) and therefore distinguishes amino acids that contribute to a positive allosteric modulator binding site from those involved in allosteric modulation of gating.

The Torpedo nAChR is comprised of five homologous subunits $\left(\alpha_{2} \beta \gamma \delta\right)$ assembled around a central axis that is perpendicular to the membrane bilayer. The transmembrane domain consists of each subunit's 4 transmembrane helices (M1-M4), 
with the five M2s lining the ion channel (Unwin, 2005). The extracellular domain of each subunit consists of a 10-strand $\beta$-sandwich with transmitter binding sites at the $\alpha-\gamma$ and $\alpha-\delta$ subunit interfaces. The $\alpha$ subunit provides the core aromatic residues ( $\alpha$ Tyr-93/ $\alpha \operatorname{Trp}-149 / \alpha \operatorname{Tyr}-190 / \alpha \mathrm{Tyr}-198)$ of the binding site principal surface, whereas amino acids from the $\gamma$ or $\delta$ subunit on a $\beta$ sheet form a rigid, complementary surface at the entry to the aromatic binding pocket. The locations of the amino acids photolabeled by $\left[{ }^{3} \mathrm{H}\right]$ physostigmine and $\left[{ }^{3} \mathrm{H}\right]$ galanthamine and the pharmacological specificity of photolabeling establish that physostigmine and galanthamine can bind at the $\alpha-\gamma$ and $\alpha-\delta$ interfaces in the absence and presence of agonist, at the noncanonical $\delta$ - $\beta$ subunit interface, and to a site in the vestibule of the ion channel.

\section{Materials and Methods}

Materials. nAChR-rich membranes were isolated from the electric organs of Torpedo californica (5 of either sex; Aquatic Research Consultants) as described previously (Middleton and Cohen, 1991). $\left[{ }^{3} \mathrm{H}\right]$ Physostigmine $(15.6 \mathrm{Ci} / \mathrm{mmol})$ and $\left[{ }^{3} \mathrm{H}\right]$ galanthamine $(10.2 \mathrm{Ci} / \mathrm{mmol})$ were from Vitrax. $\left[{ }^{3} \mathrm{H}\right]$ Phencyclidine $\left(\left[{ }^{3} \mathrm{H}\right] \mathrm{PCP} ; 27 \mathrm{Ci} / \mathrm{mmol}\right)$ was from PerkinElmer Life Sciences, and $\left[{ }^{3} \mathrm{H}\right]$ tetracaine $(30 \mathrm{Ci} / \mathrm{mmol})$ was from Sibtech.

Radioligand binding assays. The effects of physostigmine and galanthamine on the equilibrium binding of the Torpedo nAChR ion channel blockers $\left[{ }^{3} \mathrm{H}\right] \mathrm{PCP}$ and $\left[{ }^{3} \mathrm{H}\right]$ tetracaine and the agonist $\left[{ }^{3} \mathrm{H}\right] \mathrm{ACh}$ were determined as described previously (Nirthanan et al., 2008). Physostigmine and galanthamine stock solutions and Torpedo nAChR-rich membranes were prepared in Torpedo physiological saline $(250 \mathrm{~mm} \mathrm{NaCl}, 5$ $\mathrm{mm} \mathrm{KCl}, 3 \mathrm{~mm} \mathrm{CaCl}_{2}, 2 \mathrm{~mm} \mathrm{MgCl}_{2}$, and 5 mu sodium phosphate, $\mathrm{pH} 7.0$ ) containing $0.5 \mathrm{~mm}$ diisopropylphosphofluoridate to inhibit acetylcholinesterase. $\left[{ }^{3} \mathrm{H}\right]$ Tetracaine and $\left[{ }^{3} \mathrm{H}\right] \mathrm{PCP}$ binding assays were performed at $8 \mathrm{~nm}$ radioligand and $0.8 \mu \mathrm{M}$ ACh binding sites in the presence of the competitive antagonist $\alpha$-bungarotoxin $(\alpha$-BgTx, $5 \mu \mathrm{M})$ or the agonist carbamylcholine (Carb, $1 \mathrm{~mm}$ ) to stabilize the Torpedo $\mathrm{nAChR}$ in the resting or desensitized state, respectively. $\left[{ }^{3} \mathrm{H}\right] \mathrm{ACh}$ binding was performed at $15 \mathrm{~nm}$ using $40 \mathrm{~nm}$ ACh binding sites. Under these conditions, $\left[{ }^{3} \mathrm{H}\right]$ ACh occupies $\sim 20 \%$ of the transmitter binding sites, which allows the detection of either enhancement or inhibition of $\left[{ }^{3} \mathrm{H}\right] \mathrm{ACh}$ binding. Bound and free ${ }^{3} \mathrm{H}$ were separated by centrifugation $(18,000 \times g$ for $1 \mathrm{~h})$ and then quantified by liquid scintillation counting. The nonspecific binding of $\left[{ }^{3} \mathrm{H}\right] \mathrm{ACh},\left[{ }^{3} \mathrm{H}\right]$ tetracaine, or $\left[{ }^{3} \mathrm{H}\right] \mathrm{PCP}$ to Torpedo $\mathrm{nAChR}$ rich membranes was determined in the presence of Carb $(1 \mathrm{mM})$, tetracaine $(0.1 \mathrm{~mm})$, or proadifen $(0.1 \mathrm{~mm})$, respectively.

The concentration-dependent inhibition of radioligand binding was fit using a single site model:

$$
f(x)=\left\{f_{0} /\left(1+\left(x / \mathrm{IC}_{50}\right)\right)\right\}+f_{\mathrm{ns}} .
$$

where $f(x)$ is the radioligand binding in the presence of competitor at concentration $x, f_{\mathrm{o}}$ is the specific binding in the absence of competitor, $f_{\mathrm{ns}}$ is the nonspecific binding, and $\mathrm{IC}_{50}$ is the concentration of competitor that inhibits the specific binding by $50 \%$.

$\left[{ }^{3} \mathrm{H}\right]$ Physostigmine and $\left[{ }^{3} \mathrm{H}\right]$ galanthamine photolabeling of Torpedo $n A C h R$. For all experiments, nAChR-rich membranes were resuspended at $2 \mathrm{mg}$ protein $/ \mathrm{ml}(\sim 1.6 \mu \mathrm{M}$ ACh binding sites) in Torpedo physiological saline supplemented with $\sim 0.3 \mathrm{~mm}$ diisopropylphosphofluoridate and 1 mm oxidized glutathione, an aqueous scavenger. Aliquots of $125 \mu \mathrm{g}$ and $5 \mathrm{mg}$ protein per condition were used for experiments on analytical and preparative scales, respectively. Samples were incubated for $30 \mathrm{~min}$ with $1 \mu \mathrm{M}\left[{ }^{3} \mathrm{H}\right]$ physostigmine or $3 \mu \mathrm{M}\left[{ }^{3} \mathrm{H}\right]$ galanthamine, in the absence or presence of other drugs, and then irradiated, and the polypeptides were resolved on $8 \%$ polyacrylamide $/ 0.33 \%$ bis-acrylamide gels as described previously (Blanton and Cohen, 1994; Nirthanan et al., 2005).

To identify optimal photolabeling conditions, ${ }^{3} \mathrm{H}$ photoincorporation into nAChR subunits was determined by irradiating nAChR-rich membranes equilibrated with $\left[{ }^{3} \mathrm{H}\right]$ physostigmine or $\left[{ }^{3} \mathrm{H}\right]$ galanthamine for times varying from 5 to $30 \mathrm{~min}$ at different wavelengths using Spectronics model EF-16 (254 nm), EB-280C (312 nm), or EN-16 (365 nm) lamps. Photolysis at $312 \mathrm{~nm}$ for $5 \mathrm{~min}$ resulted in maximal [ ${ }^{3} \mathrm{H}$ ]physostigmine incorporation with minimum protein damage (as judged by aggregation); for $\left[{ }^{3} \mathrm{H}\right]$ galanthamine, photolysis at 312 for $10 \mathrm{~min}$ was optimal. Photodecomposition of physostigmine at $312 \mathrm{~nm}$ produces rubreserine, a chemically reactive o-quinone that can cross-link proteins (Savory and Turnbull, 1985), whereas phototolysis of galanthamine does not produce similar reactive intermediates (Marques et al., 2011). Consistent with the formation of rubreserine, we found in control experiments with nonradioactive physostigmine in Torpedo physiological saline that irradiation at $312 \mathrm{~nm}$ resulted in the formation of a red reaction product with an absorption peak at $500 \mathrm{~nm}\left(\mathrm{t}_{1 / 2} \sim 5 \mathrm{~min}\right)$. We also found by SDS-PAGE analysis that irradiation of nAChR-rich membranes with $1 \mu \mathrm{M}$ $\left[{ }^{3} \mathrm{H}\right]$ physostigmine in the presence of nonradioactive physostigmine at concentrations $>0.1 \mathrm{~mm}$, but not in the presence of galanthamine up to $1 \mathrm{~mm}$, resulted in a selective aggregation of rapsyn and a nonspecific reduction in $\left[{ }^{3} \mathrm{H}\right]$ physostigmine photolabeling in $\mathrm{nAChR}$ subunits and in non-nAChR polypeptides.

Photolabelings on an analytical scale were carried out in duplicate, with samples resolved in parallel on two acrylamide gels. After staining with Coomassie Blue R-250, the polypeptide bands were excised from one gel for ${ }^{3} \mathrm{H}$ quantification by liquid scintillation counting (Middleton and Cohen, 1991), whereas the second gel was prepared for fluorography (Amplify, GE Healthcare) and exposed to Kodak BIOMAX XAR film for $2-4$ weeks at $-80^{\circ} \mathrm{C}$ before excising polypeptide bands for ${ }^{3} \mathrm{H}$ quantification.

For preparative scale photolabelings, the $\beta$ and $\delta$ subunits were excised from the stained gel and recovered by passive elution, concentrated to a final volume of $300 \mu \mathrm{l}$ by centrifugal filtration (Vivaspin $15 \mathrm{Mr} 5000$ concentrators, Sartorius Biotech), and then acetone-precipitated (75\% acetone at $-20^{\circ} \mathrm{C}$ overnight $)$ and resuspended in digestion buffer $(15 \mathrm{~mm}$ Tris, $0.5 \mathrm{~mm}$ EDTA, $0.1 \%$ SDS, $\mathrm{pH}$ 8.1). The bands containing the nAChR $\alpha$ and $\gamma$ subunits were excised from the stained gel, soaked in overlay buffer ( $5 \%$ sucrose, $125 \mathrm{~mm}$ Tris- $\mathrm{HCl}, 0.1 \%$ SDS, $\mathrm{pH} 6.8$ ) for 30 min, and then transferred to the wells of a $15 \%$ acrylamide mapping gel and subjected to in-gel digestion (Blanton and Cohen, 1994) with $100 \mu \mathrm{g}$ of Staphylococcus aureus endoproteinase Glu-C (V8 protease, MP Biochemical). The $\alpha$ and $\gamma$ subunit mapping gels were stained with GelCode Blue (Pierce), and the subunit fragments ( $\alpha \mathrm{V} 8-20, \alpha \mathrm{V} 8-18, \alpha \mathrm{V} 8-10$, $\gamma \mathrm{V} 8-14 \mathrm{~K})$ (Blanton and Cohen, 1994) were recovered from the gel bands and resuspended in digestion buffer.

Enzymatic fragmentation. Digestions with Lysobacter enzymogenes endoproteinase Lys-C (EndoLys-C) were performed with 1 unit of EndoLys-C (Roche) for 2 weeks or with $1.25 \mu \mathrm{g}$ of EndoLys-C (6.3 unit/ $\mathrm{mg}$, Princeton Separations) for $2 \mathrm{~d}$. For digestion with TPCK-treated trypsin (Worthington Biomedical), samples in digestion buffer were diluted with $0.5 \%$ Genapol in $50 \mathrm{~mm} \mathrm{NH}_{4} \mathrm{HCO}_{3}$ buffer, $\mathrm{pH}$ 8.1, to reduce the SDS concentration to $<0.02 \%$; then an equal mass of trypsin was added in $\mathrm{CaCl}_{2}$ solution (final concentration $0.4 \mathrm{~mm}$ ) and incubated for 12-48 h. nAChR subunits were digested with $200 \mu \mathrm{g}$ V8 protease for $48 \mathrm{~h}$. All enzymatic digestions were performed at room temperature. EndoLys-C digests of $\delta$ and $\beta$ subunits were resolved on small pore (16.5\%T, 6\%C) Tricine SDS-PAGE gels (Schagger and von Jagow, 1987), and subunit fragments eluted from selected gel bands were purified by reversed-phase high performance liquid chromatography (rpHPLC). All other digests were fractionated directly by rpHPLC.

rpHPLC purification and sequence analysis. rpHPLC was performed on an HP 1100 binary system using a Brownlee Aquapore BU-300 column. Samples were eluted at $0.2 \mathrm{ml} / \mathrm{min}$ using increasing concentrations of $0.05 \%$ TFA in acetonitrile or $0.05 \%$ TFA in $60 \%$ acetonitrile $/ 40 \%$ 2-propanol. The elution of peptides and ${ }^{3} \mathrm{H}$ was monitored by the absorbance at $210 \mathrm{~nm}$ and by liquid scintillation counting of a $10 \%$ aliquot of each $0.5 \mathrm{ml}$ fraction.

For sequencing on an Applied Biosystems PROCISE 492 protein Sequencer, subunit fragments in digestion buffer and selected rpHPLC fractions were drop-loaded onto Micro TFA filters at $45^{\circ} \mathrm{C}$ or diluted with $0.1 \%$ TFA and loaded onto PVDF filters using Prosorb Sample Preparation Cartridges as described previously (Hamouda et al., 2011). Filters were treated with Biobrene after sample loading. For some sam- 
ples, sequencing was interrupted at a specific cycle and the filter was treated with $o$-phthaladehyde (OPA) before resuming sequencing (Middleton and Cohen, 1991). OPA reacts efficiently with primary amines but not with secondary amines (proline), and treatment with OPA prevents further sequencing of fragments not containing a proline at that cycle (Brauer et al., 1984). Selected samples were treated with cyanogen bromide to cleave subunit fragments at the $\mathrm{C}$ termini of methionines. The samples on sequencing filters were treated in complete darkness with $30 \mu \mathrm{l}$ of $1 \mathrm{~m}$ cyanogen bromide in $70 \%$ formic acid in water and then wrapped with a layer of Parafilm to prevent evaporation and a layer of aluminum foil to avoid light. After $24 \mathrm{~h}$ incubation at room temperature, filters were dried in a Speedvac evaporator and then sequenced. For each cycle of Edman degradation, one-sixth was used for amino acid identification/quantification and five-sixths for ${ }^{3} \mathrm{H}$ counting. The mass of amino acid detected was quantified from its peak height then fit using SigmaPlot 11 to the equation $f(x)=I_{0} R^{x}$, where $I_{0}$ is the initial amount of the peptide sequenced (in pmol), $R$ is the repetitive yield, and $f(x)$ is the pmol detected in cycle $x$. To simplify figures containing sequencing data, the masses and fit (dotted line) of detected PTH-amino acids are shown for one condition only. The efficiency of amino acid photolabeling in counts per minute per picomole $(\mathrm{cpm} / \mathrm{pmol})$ was calculated by $\left(\mathrm{cpm}_{\mathrm{x}}-\operatorname{cpm}_{(\mathrm{x}-1)}\right) / 5 I_{o} R^{\mathrm{x}}$.

Molecular modeling and computational analysis. A model of the extracellular domain of the Torpedo $\mathrm{nAChR}$ was constructed from the $\mathrm{x}$-ray structure of the Carb-bound form of the Lymnaea ACh binding protein (Celie et al., 2004) (PDB 1UV6) using the Discovery Studio (Accelrys) software package. Physostigmine was docked in the nAChR extracellular domain at the $\alpha-\gamma, \alpha-\delta$, and $\delta$ - $\beta$ subunit interfaces in the absence of Carb and also at the $\alpha-\gamma$ interface in the presence of Carb using CDOCKER (Wu et al., 2003), a CHARMm-based (Brooks et al., 2009) molecular dynamics simulated-annealing program. For each docking experiment, 30 randomly oriented replicas of physostigmine were seeded at the center of a sphere of radius $25 \AA$ containing all the amino acids at a subunit interface. At the $\alpha-\gamma$ interface, the sphere was centered at $\gamma$ Tyr- 111 for docking at the entrance to the transmitter binding site and at $\gamma$ Tyr-105 for docking in the vestibule of the ion channel. For each starting seed, CDOCKER was used to generate 10 ligand conformations using high temperature molecular dynamics. The 10 lowest energy orientations were then identified using random rigid-body rotations followed by simulated annealing and a full potential final minimization step. Docking results are shown as Connolly surface representations of the ensemble of the 30 lowest energy docking solutions, with physostigmine shown in stick format in each binding site in the orientation with lowest CDOCKER interaction energy.

\section{Results}

In initial experiments, we characterized physostigmine or galanthamine (Fig. 1A) binding to the nAChR by measuring their effects on the equilibrium binding of $\left[{ }^{3} \mathrm{H}\right] \mathrm{ACh}$ or of the channel blockers $\left[{ }^{3} \mathrm{H}\right]$ tetracaine (in the presence of the competitive antagonist $\alpha$-BgTx, which stabilizes the resting state), or $\left[{ }^{3} \mathrm{H}\right] \mathrm{PCP}$ (in the presence of the agonist Carb, which stabilizes the desensitized state). Consistent with only low-affinity binding to the agonist sites or within the ion channel (Sherby et al., 1985; Okonjo et al., 1991), physostigmine inhibited $\left[{ }^{3} \mathrm{H}\right] \mathrm{ACh},\left[{ }^{3} \mathrm{H}\right] \mathrm{PCP}$, or $\left[{ }^{3} \mathrm{H}\right]$ tetracaine binding with $\mathrm{IC}_{50} \mathrm{~s}$ of $>10,1$, and $5 \mathrm{~mm}$, respectively (Fig. $1 B$ ). Galanthamine inhibited $\left[{ }^{3} \mathrm{H}\right] \mathrm{ACh}$ binding with an $\mathrm{IC}_{50}$ of $3 \mathrm{~mm}$, whereas at $3 \mathrm{~mm}$ it inhibited $\left[{ }^{3} \mathrm{H}\right] \mathrm{PCP}$ and $\left[{ }^{3} \mathrm{H}\right]$ tetracaine binding by 20 and $10 \%$, respectively (Fig. $1 C$ ).

\section{Photolabeling the nAChR with $\left[{ }^{3} \mathrm{H}\right]$ physostigmine}

When adult muscle $\mathrm{nAChR}$ is exposed to low micromolar concentrations of physostigmine or galanthamine, single-channel responses are observed that appear independent of direct binding to the classic transmitter sites (Akk et al., 2005; Militante et al., 2008). Similar $\alpha$-BgTx-insensitive single-channel responses are seen for Torpedo $\mathrm{nAChR}$ exposed to $1 \mu \mathrm{M}$ physostigmine (Mael-
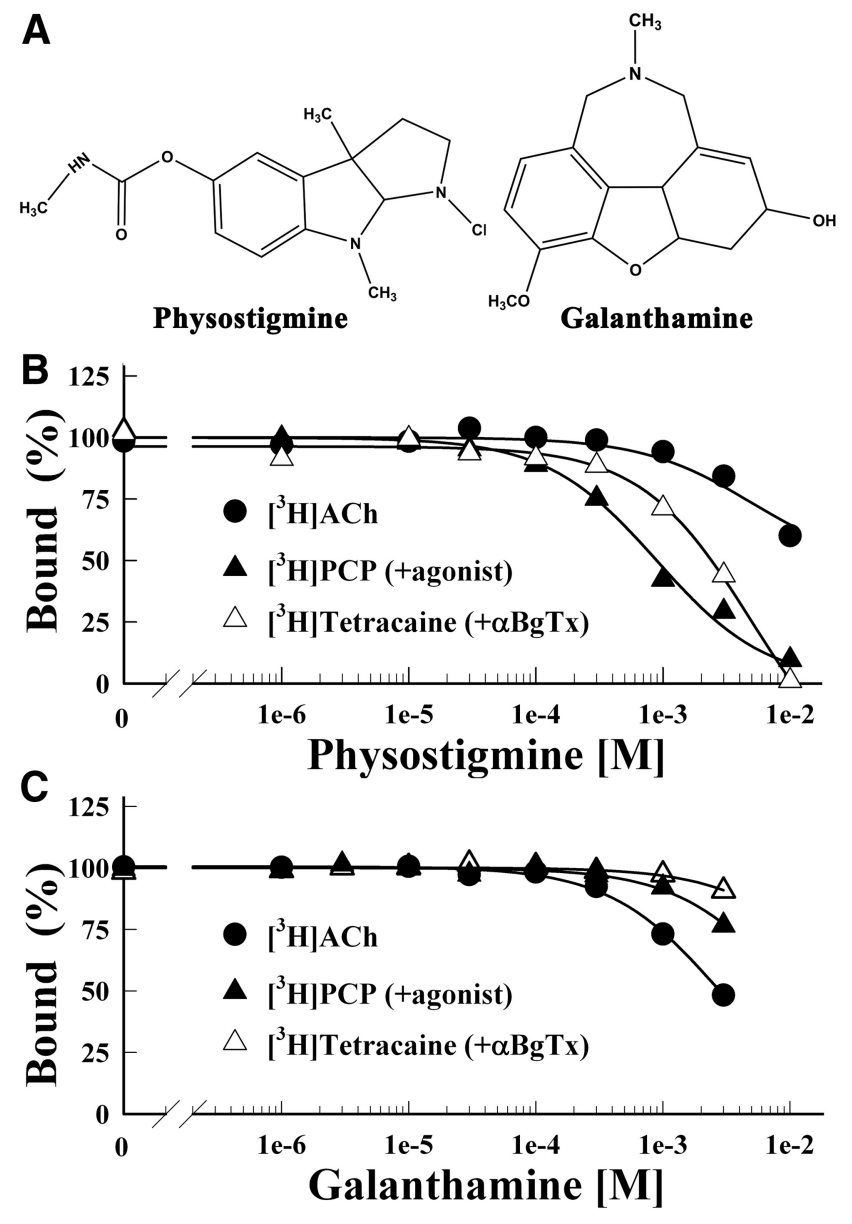

Figure 1. Physostigmine and galanthamine inhibition of the equilibrium binding of $\left[{ }^{3} \mathrm{H}\right] \mathrm{ACh},\left[{ }^{3} \mathrm{H}\right]$ tetracaine, and $\left[{ }^{3} \mathrm{H}\right] \mathrm{PCP}$ to the Torpedo nAChR. $\boldsymbol{A}$, The chemical structures of physostigmine and galanthamine. $\boldsymbol{B}, \boldsymbol{C}$, The equilibrium binding of $\left[{ }^{3} \mathrm{H}\right] \mathrm{ACh}(\mathbf{O}),\left[{ }^{3} \mathrm{H}\right]$ tetracaine $(+\alpha-B g T x, \triangle)$, or $\left[{ }^{3} \mathrm{H}\right] \mathrm{PCP}(+\mathrm{Carb}, \mathbf{\Delta})$ was determined using centrifugation assays in the absence or presence of increasing concentrations of physostigmine $(\boldsymbol{B})$ or galanthamine $(\boldsymbol{C})$. For each competition experiment, the data were normalized to the specific binding in the absence of competitor. Total binding for [ $\left.{ }^{3} \mathrm{H}\right] \mathrm{ACh}$ was $1313 \pm 5 \mathrm{cpm}$, with $88 \pm 10 \mathrm{cpm}$ nonspecific (+ $1 \mathrm{~mm}$ (arb); for $\left[{ }^{3} \mathrm{H}\right]$ tetracaine, $24,400 \pm 120 \mathrm{cpm}$, with $5583 \pm 16 \mathrm{cpm}$ nonspecific ( $+100 \mu \mathrm{m}$ tetracaine); for $\left[{ }^{3} \mathrm{H}\right] \mathrm{PCP}, 6854 \pm 52 \mathrm{cpm}$, with $437 \pm 6$ cpm nonspecific (+ $100 \mu \mathrm{m}$ Proadifen). Physostigmine inhibited $\left[{ }^{3} \mathrm{H}\right]$ tetracaine and $\left[{ }^{3} \mathrm{H}\right] \mathrm{PCP}$ binding with $\mathrm{IC}_{50} \mathrm{~s}$ of $5 \pm 1 \mathrm{~mm}$ and $0.9 \pm 0.1 \mathrm{~mm}$, respectively. Galanthamine inhibited [ $\left.{ }^{3} \mathrm{H}\right] \mathrm{ACh}$ binding with $\mathrm{IC}_{50}=2.8 \pm 0.1 \mathrm{~mm}$.

icke et al., 1997), whereas galanthamine at $1 \mu \mathrm{M}$ enhances ACh responses at submaximal doses (Texidó et al., 2005). Because physostigmine and galanthamine at higher concentrations inhibit nAChR responses, we photolabeled Torpedo nAChR with $\left[{ }^{3} \mathrm{H}\right]$ physostigmine or $\left[{ }^{3} \mathrm{H}\right]$ galanthamine at $\sim 1 \mu \mathrm{M}$ to favor identification of binding sites relevant for positive allosteric modulation.

When Torpedo nAChR-rich membranes were photolabeled with $1 \mu \mathrm{M}\left[{ }^{3} \mathrm{H}\right]$ physostigmine and the polypeptides were resolved by SDS-PAGE (Fig. 2 ), $\left[{ }^{3} \mathrm{H}\right]$ physostigmine was photoincorporated in the absence of agonist into each nAChR subunit and into rapsyn, a peripheral protein associating with the cytoplasmic aspect of the $\mathrm{nAChR}$. Inclusion of $1 \mathrm{~mm}$ nonradioactive physostigmine, but not Carb or galanthamine, resulted in the selective aggregation of rapsyn and an apparent nonselective reduction of ${ }^{3} \mathrm{H}$ incorporation in all polypeptides, probably as a result of the formation of rubreserine (see $\left[{ }^{3} \mathrm{H}\right]$ physostgimine photolabeling, Materials and Methods). Based upon counting of 
excised gel slices (Fig. 2B), Carb or $\alpha$-BgTx reduced photoincorporation into the nAChR $\alpha$ subunit by $40 \%$ and into the $\gamma$ subunit by $10 \%$ and $20 \%$, respectively, whereas photoincorporation was altered by $<5 \%$ in the $\mathrm{nAChR} \beta$ subunit or in the $\mathrm{Na}^{+} / \mathrm{K}^{+}$-ATPase $\alpha$ subunit (from contaminating membrane fragments). Carb increased and $\alpha$-BgTx decreased photolabeling of the nAChR $\delta$ subunit by $\sim 10 \%$. In the presence of Carb or $\alpha$-BgTx, nonradioactive physostigmine at $100 \mu \mathrm{M}$ decreased $\left[{ }^{3} \mathrm{H}\right]$ physostigmine photolabeling in the nAChR subunits by $25-40 \%$ but by $<5 \%$ the $\mathrm{Na}^{+} / \mathrm{K}^{+}$-ATPase $\alpha$ subunit (Fig. $2 B$ ). Because of the nonspecific effects of physostigmine at $1 \mathrm{~mm}$, we did not further characterize it as an inhibitor of $\left[{ }^{3} \mathrm{H}\right]$ physostigmine photolabeling. In the presence of Carb, galanthamine at $1 \mathrm{~mm}$ reduced $\left[{ }^{3} \mathrm{H}\right]$ physostigmine photoincorporation into the nAChR subunits to the same extent as $100 \mu \mathrm{M}$ physostigmine (data not shown).

$\left[{ }^{3} \mathrm{H}\right]$ Physostigmine photolabels core aromatic amino acids of the transmitter binding site

The Carb and $\alpha$-BgTx inhibitable photolabeling of the nAChR $\alpha$ subunit indicates that $\left[{ }^{3} \mathrm{H}\right]$ physostigmine probably binds in the transmitter binding site and photolabels one or more of the core aromatic amino acid side chains ( $\alpha$ Tyr-93, $\alpha$ Trp$149, \alpha$ Tyr-190, and $\alpha$ Tyr-198) of the $\alpha$ subunit that coordinate the trimethyl ammonium group of ACh. To examine that, $\left[{ }^{3} \mathrm{H}\right]$ physostigmine-photolabeled $\alpha$ subunit was digested in gel with V8 protease, which produces $\alpha$ subunit fragments with apparent molecular masses of $\sim 20 \mathrm{kDa}$ $(\alpha \mathrm{V} 8-20), \sim 18 \mathrm{kDa}(\alpha \mathrm{V} 8-18)$, and $\sim 10$ $\mathrm{kDa}(\alpha \mathrm{V} 8-10)$ (Blanton and Cohen, 1994). Within the primary structure of the $\alpha$ subunit, the $\alpha \mathrm{V} 8-18$ fragment begins at $\alpha$ Thr-52 and contains the agonist binding site (ABS) segments A ( $\alpha$ Tyr-93) and B ( $\alpha$ Trp-149); the $\alpha \mathrm{V} 8-20$ fragment begins at $\alpha$ Ser-173 and contains the ABS segment C ( $\alpha$ Tyr-190, $\alpha$ Tyr-198) and the M1M2-M3 transmembrane helices; and the $\alpha \mathrm{V} 8-10$ fragment, which begins at $\alpha$ Asn-338, extends to the $\mathrm{C}$ terminus and contains the cytoplasmic MA helix and M4 (Unwin, 2005).

The majority ( $\sim 80 \%$ ) of ${ }^{3} \mathrm{H}$ incorporated in the $\alpha$ subunit was contained in the $\alpha \mathrm{V} 8-20$ fragment, with either Carb or $\alpha$-BgTx inhibiting $\alpha \mathrm{V} 8-20$ photolabeling by $>75 \%$. Direct sequencing of $\left[{ }^{3} \mathrm{H}\right.$ ] physostigmine-photolabeled $\alpha \mathrm{V} 8-20$ (Fig. $3 A, B)$ revealed major peaks of ${ }^{3} \mathrm{H}$ release in cycles 18,20 , and 26 that established photolabeling of $\alpha$ Tyr-190, $\alpha$ Cys-192, and $\alpha$ Tyr- 198 at 10,10 , and $20 \mathrm{cpm} / \mathrm{pmol}$, respectively. Photolabeling of those amino acids was inhibited by $>85 \%$ in the presence of Carb (Fig. 3A) or $\alpha$-BgTx (Fig. 3B). Quantification of photolabeling efficiencies indicated that photolabeling of $\alpha$ Tyr-190 and $\alpha$ Tyr-198 was at least 10 times greater than
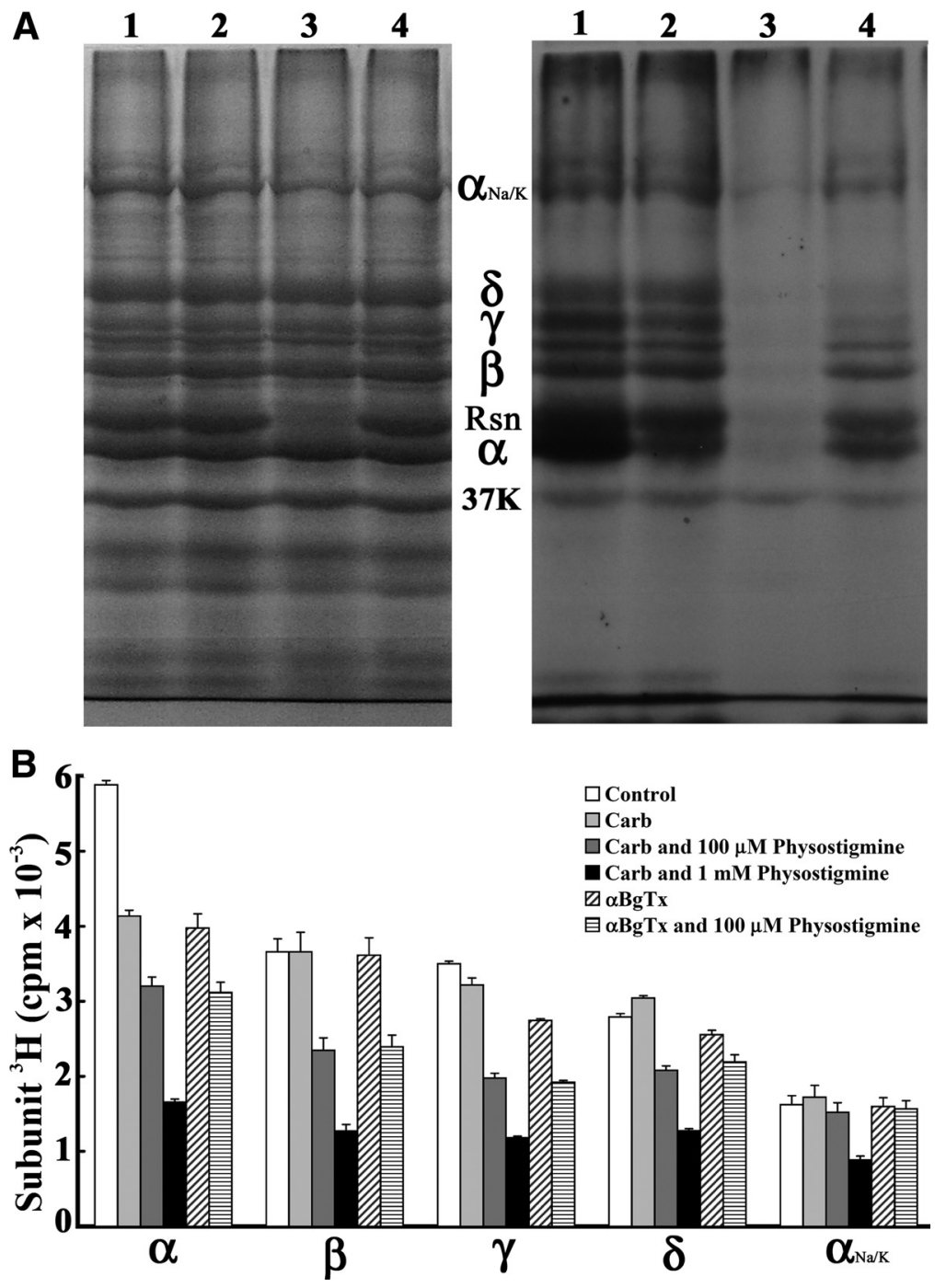

Figure 2. $\left[{ }^{3} \mathrm{H}\right]$ Physostigmine photoincorporation into the Torpedo $\mathrm{nAChR}$. Torpedo nAChR-rich membranes at $2 \mathrm{mg}$ protein $/ \mathrm{ml}$ (150 pmol ACh binding site/condition) were photolabeled with $1 \mu \mathrm{m}\left[{ }^{3} \mathrm{H}\right]$ physostigmine in the absence or presence of cholinergic ligands, and the membrane polypeptides were resolved on two parallel SDS-PAGE gels. Gels were stained with Coomassie Blue with membranes in lanes $1-4$ photolabeled by $\left[{ }^{3} \mathrm{H}\right]$ physostgimine: (1) in the absence of other drugs; $(2)+1 \mathrm{~mm} \mathrm{Carb;} \mathrm{(3)}+1 \mathrm{~mm}$

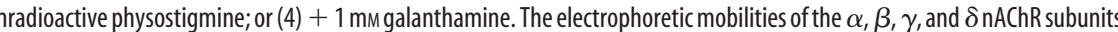
in the polypeptide bands excised from two gels containing nAChR-rich membranes photolabeled with $\left[{ }^{3} \mathrm{H}\right]$ physostigmine in the absence or presence of Carb, $\alpha$-BgTx, or physostigmine.

that of any other aromatic residues within that sequence (Fig. 3C)

$\left[{ }^{3} \mathrm{H}\right]$ Physostigmine photoincorporation within $\alpha \mathrm{V} 8-18$, which contains $\alpha$ Tyr-93 and $\alpha$ Trp-149, was at $<20 \%$ the level of $\alpha \mathrm{V} 8-20 .{ }^{3} \mathrm{H}$ incorporation within $\alpha \mathrm{V} 8-18$ was recovered in a single peak when an EndoLys-C digest of $\alpha \mathrm{V} 8-18$ was fractionated by rpHPLC. Sequence analysis of ${ }^{3} \mathrm{H}$ peak fractions identified a $\left[{ }^{3} \mathrm{H}\right]$ physostigmine-photolabeled peptide beginning at $\alpha$ Ile-78 and a peak of ${ }^{3} \mathrm{H}$ release at cycle 16 that established photolabeling of $\alpha$ Tyr-93 (2 cpm/pmol) that was inhibited by $>90 \%$ by Carb (data not shown). Photolabeling of $\alpha$ Trp-149 was not determined directly. However, the low level of ${ }^{3} \mathrm{H}$ incorporation within $\alpha \mathrm{V} 8-18$ relative to $\alpha \mathrm{V} 8-20$ indicates that photolabeling of $\alpha \operatorname{Trp}-149$, if it occurs, will not be higher than the level of photolabeling of $\alpha$ Tyr-93, i.e., $\sim 10 \%$ the efficiency of photolabeling $\alpha$ Tyr-198. 

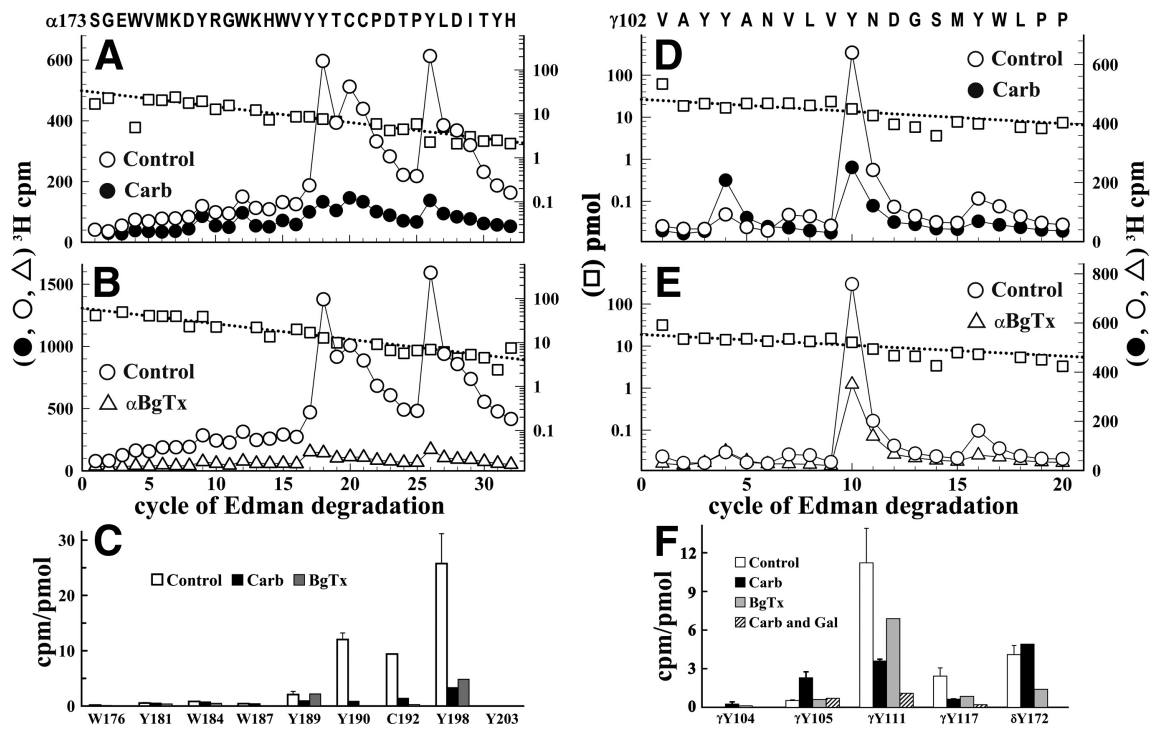

Figure 3. $\left[{ }^{3} \mathrm{H}\right]$ Physostigmine photolabeling at the $\alpha$ - $\gamma$ extracellular interface in the presence or absence of Carb or $\alpha-\mathrm{BgTx} . \mathrm{A}$ $\boldsymbol{B}, \boldsymbol{D}, \boldsymbol{E},{ }^{3} \mathrm{H}(\bigcirc, \boldsymbol{O}, \triangle)$ and $\mathrm{PTH}$-amino acids $(\square)$ released during sequence analysis of fragments beginning at $\alpha$ Ser-173 $(\boldsymbol{A}, \boldsymbol{B})$ and $\gamma$ Val-102 $(\boldsymbol{D}, \boldsymbol{E})$ isolated from Torpedo $\mathrm{nAChR}$ photolabeled with $\left[{ }^{3} \mathrm{H}\right]$ physostigmine in the absence of other drugs $(\boldsymbol{A}, \boldsymbol{B}, \boldsymbol{D}, \boldsymbol{E}, \mathrm{O}$, $\square$ ), in the presence of $1 \mathrm{~mm} \operatorname{Carb}(\boldsymbol{A}, \boldsymbol{D}, \mathbf{O})$, or in the presence of $8 \mu \mathrm{m} \alpha-\operatorname{BgTx}(B, E, \triangle) . C, F$, Quantification of $\left[{ }^{3} H\right]$ physostigmine photoincorporation (in $\mathrm{cpm} / \mathrm{pmol}$ ) into aromatic amino acid residues within the primary structure of fragment beginning at $\alpha$ Ser-173 $(\boldsymbol{C})$ or $\gamma \mathrm{Val}-102(\boldsymbol{F})$. For the control and + Carb conditions, the values plotted are the mean \pm SD from two independent photolabeling experiments, whereas data for $+\alpha$-BgTx are from a single experiment. To calculate the efficiency of labeling at $\alpha$ Cys-192 (cycle 20) from sequencing data shown in $A$, the background ${ }^{3} \mathrm{H}$ release in cycle 20 originating from the photolabeling of $\alpha$ Tyr-190 in cycle 18 was estimated by fitting the observed ${ }^{3} \mathrm{H}$ releases in cycles 18,19 , and 25 to an exponential decay. $\boldsymbol{F}$, Also included are values from a third $\left[{ }^{3} \mathrm{H}\right]$ physostigmine preparative photolabeling in the presence of Carb or Carb and galanthamine and the efficiency of photolabeling of $\delta$ Tyr-172, derived from sequencing data presented in Figure 4.

\section{$\left[{ }^{3} \mathrm{H}\right]$ Physostigmine photolabels the complementary surface} of the transmitter binding sites in the absence and presence of Carb or $\alpha$-BgTx

Amino acids of the $\gamma$ or $\delta$ subunit that contribute to the transmitter binding sites are located on $\beta$ strands 2 (ABS Segment $\mathrm{D}$ ) and 5/6 (ABS Segment $\mathrm{E}$ ) that are part of a 4 -strand antiparallel $\beta$ sheet forming a rigid surface at the entry to the aromatic binding pocket, and in a stretch of amino acids (ABS Segment F) between $\beta$ strands 8 and 9 (Celie et al., 2004; Hansen et al., 2005; Unwin, 2005).

Upon in-gel digestion of $\left[{ }^{3} \mathrm{H}\right]$ physostigmine-photolabeled $\gamma$ subunit with V8 protease, $>90 \%$ of ${ }^{3} \mathrm{H}$ was recovered in a $14-\mathrm{kDa}$ gel band $(\gamma \mathrm{V} 8-14)$, known to contain the fragment beginning at $\gamma$ Val-102 that extends through ABS Segment E (Chiara and Cohen, 1997). rpHPLC purification of $\gamma \mathrm{V} 8-14$ resulted in a single, hydrophilic peak of ${ }^{3} \mathrm{H}$. Sequence analysis of this peak confirmed the presence of the fragment beginning at $\gamma \mathrm{Val}-102$ and revealed a major peak of ${ }^{3} \mathrm{H}$ release at cycle 10 of Edman degradation, with smaller peaks in cycles 4 and 16 (Fig. 3D), establishing that $\left[{ }^{3} \mathrm{H}\right]$ physostigmine photolabeled $\gamma \mathrm{Tyr}-105(0.5 \mathrm{cpm} / \mathrm{pmol})$, $\gamma$ Tyr-111 $(9 \mathrm{cpm} / \mathrm{pmol})$, and $\gamma \mathrm{Tyr}-117(2 \mathrm{cpm} / \mathrm{pmol})$. Photolabeling of $\gamma$ Tyr- 111 and $\gamma$ Tyr- 117 was inhibited by $50-60 \%$ in the presence of Carb (Fig. 3D) or $\alpha$-BgTx (Fig. 3E), whereas photolabeling of $\gamma$ Tyr-105 was enhanced in the presence of Carb but unchanged in the presence of $\alpha$-BgTx (Fig. 3F). In the presence of Carb, nonradioactive galanthamine at $300 \mu \mathrm{M}$ inhibited $\left[{ }^{3} \mathrm{H}\right]$ physostigmine photolabeling of $\gamma \mathrm{Tyr}-105, \gamma \mathrm{Tyr}-111$, and $\gamma$ Tyr-117 by $\sim 75 \%$ (Fig. $3 F$ ).

We also characterized photolabeling within $\delta$ subunit fragments beginning at $\delta \mathrm{Glu}-47$, which contains $\delta \operatorname{Trp}-59$, the core aromatic amino acid of ABS Segment D, and $\delta$ Asp-171, containing amino

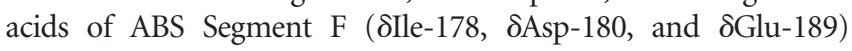

(Czajkowski et al., 1993; Prince and Sine, 1996). The fragment beginning at $\delta \mathrm{Glu}-47$ was isolated from an Endo Lys-C digest of $\left[{ }^{3} \mathrm{H}\right]$ physostigmine-photolabeled $\delta$ subunit by Tricine-SDS-PAGE and rpHPLC (Garcia et al., 2007), whereas the fragment beginning $\delta$ Asp-171 was isolated directly from the digest by rpHPLC.

Sequencing the fragment beginning at ¿Glu-47 (data not shown) revealed photolabeling of $\delta \operatorname{Trp}-57(0.8 \mathrm{cpm} / \mathrm{pmol})$; any photolabeling of adjacent aromatic amino acids ( $\delta$ Trp-64, $\delta$ Tyr-65), if it occurred, was at $<0.2 \mathrm{cpm} / \mathrm{pmol}$. Sequencing the fragment beginning at $\delta$ Asp-171 revealed Carb-independent $\left[{ }^{3} \mathrm{H}\right]$ physostigmine photolabeling of $\delta \mathrm{Tyr}-172(4$ $\mathrm{cpm} / \mathrm{pmol}$; Fig. $4 A$ ). In contrast, $\alpha$-BgTx reduced photolabeling of $\delta$ Tyr-172 by $70 \%$ (Fig. 4B). We did not attempt to characterize photolabeling in the $\delta$ subunit ABS Segment $E$ because of the difficulty of achieving the necessary efficient cleavage at $\delta$ Asp-97 (Nirthanan et al., 2005).

\section{$\left[{ }^{3} \mathrm{H}\right]$ Physostigmine photolabels $\delta$ Tyr-212 at the $\delta$ - $\beta$ subunit extracellular interface}

To determine whether $\left[{ }^{3} \mathrm{H}\right]$ physostigmine and galanthamine might bind in the nAChR extracellular domain at interfaces not containing $\alpha$ subunits, we characterized photolabeling in an $\sim 10-\mathrm{kDa} \delta$ subunit fragment that begins at $\delta$ Phe- 206 and extends through $\beta$ strand 10 and $\delta \mathrm{M} 1$. This fragment was isolated by SDS-PAGE and rpHPLC from EndoLys-C digests of photolabeled $\delta$ subunit (Garcia et al., 2007). Sequence analysis of this fragment (Fig. 5) revealed a single peak of ${ }^{3} \mathrm{H}$ release in cycle 7 that established photolabeling of $\delta \mathrm{Tyr}-212$, which is located in the $\delta$ subunit primary structure at a position equivalent to $\alpha \mathrm{Tyr}-198$ of the ABS Segment C. The efficiency of photolabeling of $\delta \mathrm{Tyr}-212$ was doubled in the presence of Carb (Fig. 5A) and reduced by $\sim 25 \%$ in the presence of $\alpha$-BgTx (Fig. $5 B$ ). For nAChRs photolabeled in the presence of Carb, galanthamine inhibited $\delta$ Tyr-212 photolabeling by $\sim 50 \%$ (Fig. $5 \mathrm{C}$ ). The efficiency of photolabeling of $\delta$ Tyr- 212 in the presence of Carb $(1.5 \mathrm{cpm} / \mathrm{pmol})$ was $>10$-fold higher than the photolabeling, if it occurred, of $\delta \mathrm{Tyr}-218$ or $\delta \mathrm{Tyr}-228$, which are contained in the same $\delta$ subunit fragment, or of $\delta \mathrm{Tyr}-202$, which was characterized by sequencing a longer fragment produced by an alternative cleavage before $\delta$ Asn- 200 . The efficiency of $\left[{ }^{3} \mathrm{H}\right.$ ] physostigmine labeling at $\delta \mathrm{Tyr}-212$ in the absence of agonist was similar to the $\left[{ }^{3} \mathrm{H}\right]$ physostigmine photolabeling of $\delta$ Tyr- 439 within the $\delta$ subunit cytoplasmic MA helix, the only other photolabeled tyrosine identified within $\delta$ subunit. However, the efficiency of photolabeling at $\delta \mathrm{Tyr}-439(1 \mathrm{cpm} /$ pmol) was changed by $<20 \%$ in the presence of Carb, $\alpha$-BgTx or galanthamine.

Sites and pharmacology of $\left[{ }^{3} \mathrm{H}\right]$ galanthamine photolabeling mirrors $\left[{ }^{3} \mathrm{H}\right]$ physostigmine photolabeling

When nAChRs were photolabeled on an analytical scale with 3 $\mu \mathrm{M}\left[{ }^{3} \mathrm{H}\right]$ galanthamine, photolabeling in the $\alpha$ subunit was inhibited by $80 \%$ in the presence of Carb. The other subunits were also 


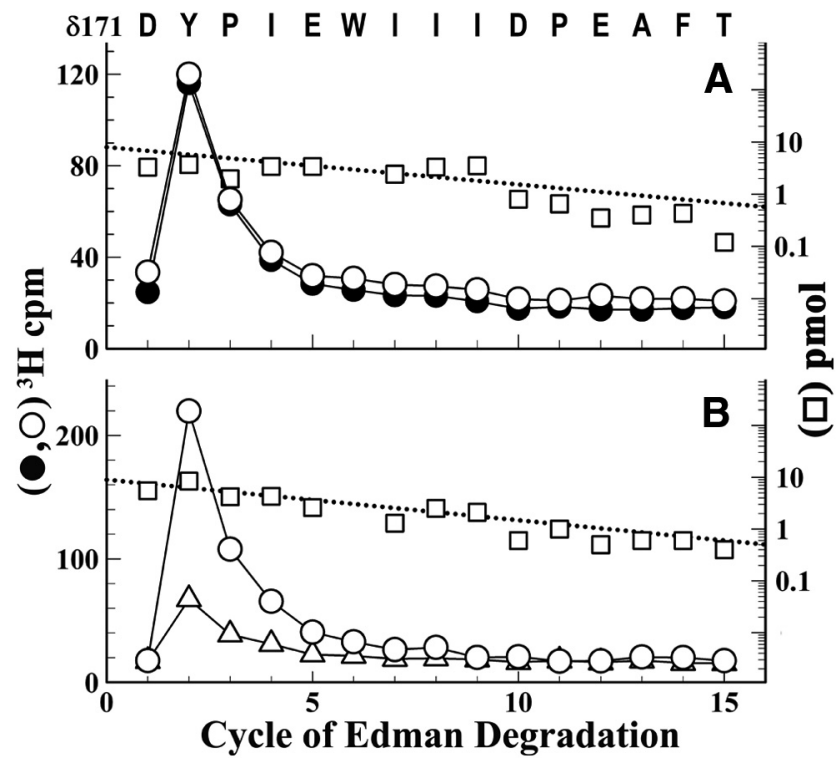

Figure 4. $\left[{ }^{3} \mathrm{H}\right]$ Physostigmine photolabels $\delta \mathrm{Tyr}-172$ in the absence and presence of Carb or $\alpha$-BgTx. ${ }^{3} \mathrm{H}(O, \bullet, \triangle)$ and PTH-amino acids $(\square)$ released during sequence analysis of a $\delta$ subunit fragment beginning at $\delta A s p-171$ that was isolated from $n A C h R s$ photolabeled with $\left[{ }^{3} \mathrm{H}\right]$ physostigmine in the absence of other drugs $(\bigcirc, \square)$, or presence of $1 \mathrm{~mm} \mathrm{Carb}(\bigcirc)$ or $8 \mu \mathrm{m}$ $\alpha$-BgTx $(\triangle)$. $\boldsymbol{A}, \boldsymbol{B}$, The peaks of ${ }^{3} \mathrm{H}$ release at cycle 2 indicate photolabeling of $\delta$ Tyr-172 that was potentiated in the presence of $\operatorname{Carb}(\boldsymbol{A},-/+C \mathrm{Carb}, 3.4 / 4.9 \mathrm{cpm} / \mathrm{pmol})$ but inhibited in the presence of $\alpha-\mathrm{BgTx}(\boldsymbol{B},-/+\alpha-\mathrm{BgTx}, 5 / 1.6 \mathrm{cpm} / \mathrm{pmol})$. The subunit fragment beginning at $\delta$ Asp-171was isolated by rpHPLC fractionation of an Endo Lys-C digest of $\delta$ subunit.

photolabeled, but at lower efficiency, with Carb reducing photolabeling in $\gamma$ and $\delta$ by $\sim 25 \%$ and in $\beta$ by $<5 \%$. For nAChRs photolabeled in the presence of Carb, nonradioactive galanthamine at $100 \mu \mathrm{M}$ reduced photolabeling of each nAChR subunit by $\sim 25 \%$, whereas photolabeling of the $\mathrm{Na}^{+} / \mathrm{K}^{+}$-ATPase $\alpha$ subunit was reduced by $<5 \%$.

For nAChRs photolabeled by $\left[{ }^{3} \mathrm{H}\right]$ galanthamine in the absence or presence of Carb, amino acid sequence analysis of the $\alpha$ subunit fragment beginning at $\alpha$ Ser- 173 established $\left[{ }^{3} \mathrm{H}\right.$ ] galanthamine photolabeling of $\alpha \mathrm{Tyr}-190$ and $\alpha \mathrm{Tyr}-198$ that was inhibited by $>95 \%$ in the presence of Carb (Fig. 6A). We also characterized $\left[{ }^{3} \mathrm{H}\right]$ galanthamine photolabeling within ABS Segment $\mathrm{E}$ of the $\gamma$ subunit by sequence analysis of the fragment beginning at $\gamma \mathrm{Val}-102$ (Fig. $6 \mathrm{~B}$ ). The photolabeled amino acids ( $\gamma \mathrm{Tyr}-105, \gamma \mathrm{Tyr}-111$, and $\gamma \mathrm{Tyr}-117)$ and the effect of Carb on $\left[{ }^{3} \mathrm{H}\right]$ galanthamine photolabeling (partial inhibition at $\gamma \mathrm{Tyr}-111$ and enhancement at $\gamma \mathrm{Tyr}-105$ ) were remarkably similar to those for $\left[{ }^{3} \mathrm{H}\right]$ physostigmine. $\left[{ }^{3} \mathrm{H}\right]$ Galanthamine also photolabeled $\delta$ Tyr-172 within $\delta$ subunit ABS Segment $\mathrm{F}$ in the absence and presence of Carb (Fig. 6C) and $\delta$ Tyr-212 in the presence of Carb (Fig. 6D, the only condition examined).

\section{Photolabeling of $\alpha$ Lys-125?}

An early characterization of photolabeling of Torpedo nAChRrich membranes by $50 \mu \mathrm{M}\left[{ }^{3} \mathrm{H}\right]$ physostigmine (Schrattenholz et al., 1993) reported the selective photolabeling of one amino acid, $\alpha$ Lys-125, which is located in the extracellular domain on $\beta$ strand 6 projecting into the vestibule of the ion channel at an interface with a $\beta$ or $\gamma$ subunit. Under our conditions of photolabeling at $1 \mu \mathrm{M}\left[{ }^{3} \mathrm{H}\right]$ physostigmine, we found that any photolabeling of $\alpha$ Lys- 125 or the adjacent $\alpha$ Tyr-127, if it occurred, was at $<0.2$ and $0.05 \mathrm{cpm} / \mathrm{pmol}$, respectively. This was determined by sequence analysis of $\alpha$ subunit fragments beginning at $\alpha \operatorname{Trp}-118 /$

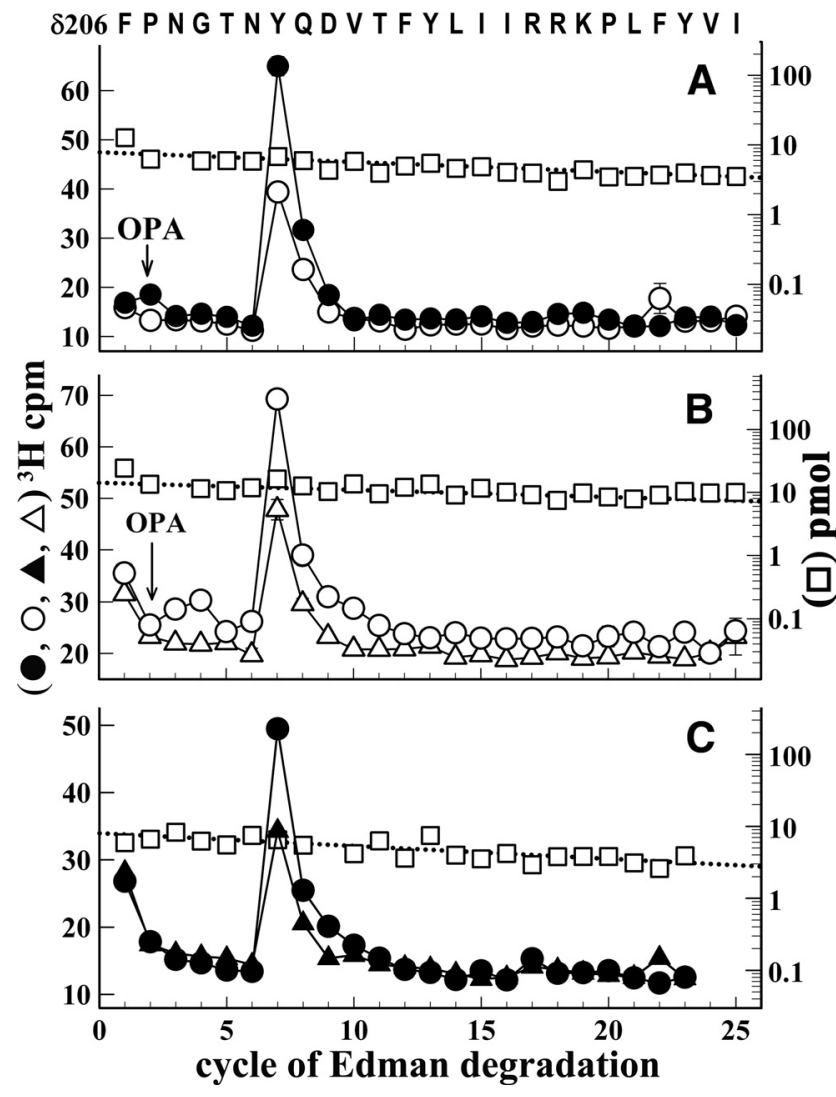

Figure 5. $\left[{ }^{3} \mathrm{H}\right]$ Physostigmine photolabels $\delta$ Tyr-212 at the $\delta$ - $\beta$ interface in the $\mathrm{nAChR}$ extracellular domain. $\boldsymbol{A}-\mathrm{C},{ }^{3} \mathrm{H}(\mathrm{O}, \mathbf{O}, \triangle, \mathbf{\Delta})$ and PTH-amino acids $(\square)$ released during sequence analysis of a fragment beginning at $\delta$ Phe-206 isolated from nAChRs photolabeled with $\left[{ }^{3} \mathrm{H}\right]$ physostigmine in the absence of other drugs $(\boldsymbol{A}, \boldsymbol{B}, \bigcirc, \square)$, or in the presence of $1 \mathrm{~mm}$ Carb $(\boldsymbol{A}, \boldsymbol{C}, \mathbf{O}$,$) , or 8 \mu \mathrm{m} \alpha-\operatorname{BgTx}(\boldsymbol{B}, \triangle)$ or $1 \mathrm{~mm}$ Carb and $300 \mu \mathrm{m}$ galanthamine $(\boldsymbol{C}, \mathbf{A})$. This fragment was isolated by rpHPLC purification of polypeptides eluted from a 10 to $14 \mathrm{kDa}$ band from a Tricine SDS-PAGE fractionation of EndoLys-C digests of the $\delta$ subunit. The calculated efficiencies of $\left[{ }^{3} \mathrm{H}\right]$ physostigmine photolabeling of $\delta$ Tyr-212 (cycle 7) in the different conditions are shown in Table 1. The arrow and OPA at cycle 2 indicate that sequencing was interrupted and the filter was treated with OPA before resuming sequencing (see Materials and Methods for protein sequencing).

$\alpha$ Thr-119, which were produced by cyanogen bromide cleavage of rpHPLC-purified $\alpha \mathrm{V} 8-18$. While we detected photolabeling only of tyrosines and cysteines, it is likely that different photolysis conditions will favor the formation of rubreserine, a chemically reactive $o$-quinone decomposition product of physostigmine (Savory and Turnbull, 1985) that reacts efficiently with the primary amine of lysine. However, because $o$-quinones do not react with tyrosines (Pierpoint, 1969), the photolabeled nAChR tyrosines that we have identified reflect photolabeling by $\left[{ }^{3} \mathrm{H}\right]$ physostigmine and not by an $o$-quinone decomposition product.

\section{Discussion}

In this work, we use the intrinsic photoreactivities of $\left[{ }^{3} \mathrm{H}\right]$ physostigmine and $\left[{ }^{3} \mathrm{H}\right]$ galanthamine to identify their binding sites in a muscle-type nAChR. Under our photolabeling conditions, both drugs photoincorporate primarily into tyrosines. The locations of the photoabeled residues in a homology model of the Torpedo nAChR extracellular domain based upon the structure of the Lymnea ACh binding protein (AChBP) (Celie et al., 2004) (Fig. 7) and the pharmacological specificity of photolabeling establish that, in the presence of agonist, each drug binds in the nAChR 

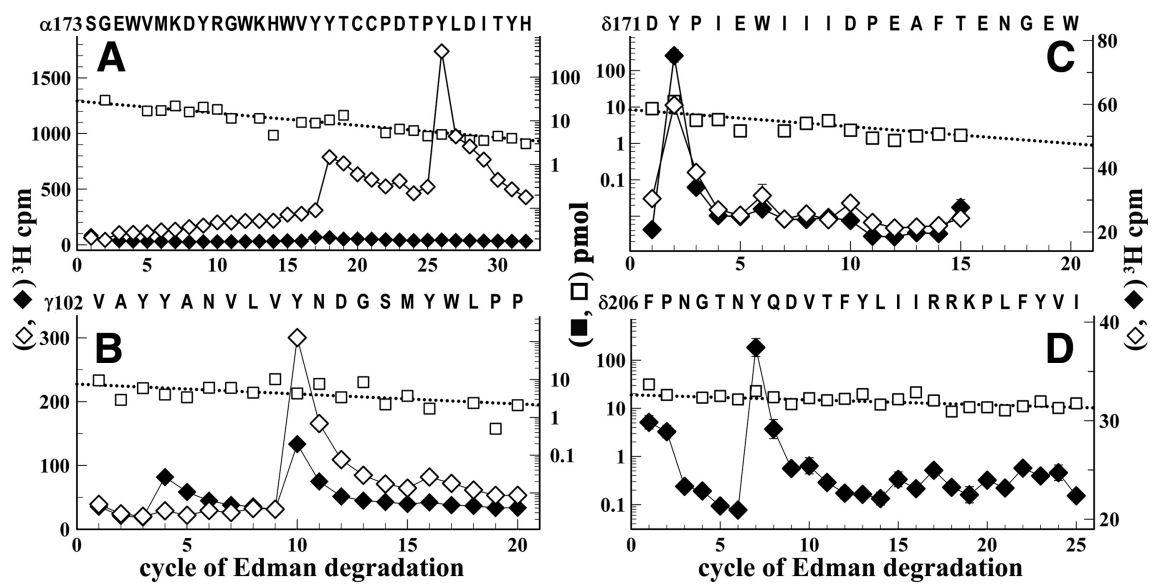

Figure 6. $\left[{ }^{3} \mathrm{H}\right] \mathrm{Galanthamine} \mathrm{photolabels} \mathrm{amino} \mathrm{acids} \mathrm{at} \mathrm{the} \alpha-\gamma, \alpha-\delta$, and $\delta$ - $\beta$ extracellular interfaces in the absence and presence of agonist. $\boldsymbol{A}-\boldsymbol{D},{ }^{3} \mathrm{H}(\diamond, \diamond)$ and PTH-amino acids $(\square)$ released during sequence analysis of subunit fragments beginning at $\alpha$ Ser-173 $(\boldsymbol{A}), \gamma$ Val-102 $(\boldsymbol{B}), \delta$ Asp-171 $(\boldsymbol{C})$, and $\delta$ Phe-206 $(\boldsymbol{D})$ isolated from Torpedo nAChRs photolabeled with $\left[{ }^{3} \mathrm{H}\right.$ ]galanthamine in the absence $(\diamond)$ or presence of $\mathrm{Carb}(\diamond)$. These fragments were isolated as described in the text and figure legends for the corresponding $\left[{ }^{3} \mathrm{H}\right]$ physostigmine-photolabeled fragments. The efficiencies of amino acid photolabeling ( $-\mathrm{Carb} /$ + Carb, in cpm/pmol) calculated from the peaks of ${ }^{3} \mathrm{H}$ release and the PTH-amino acid mass levels were as follows: $\boldsymbol{A}$, in cycles 18 and 26, $\alpha$ Tyr-190 (11/0.8) and $\alpha$ Tyr-198 (45/0.1); $\boldsymbol{B}$, in cycles 5, 10 and 15, $\gamma$ Tyr-105 (0.3/2.1), $\gamma$ Tyr-111 (12.6/5), and $\gamma$ Tyr-117 (1.2/0.2); $\boldsymbol{C}$, in cycle 2, $\delta$ Tyr-172 (1.1/1.6 cpm/pmol); $\boldsymbol{D}$, in cycle 7, $\delta$ Tyr-212 (+Carb, $0.2 \mathrm{cpm} / \mathrm{pmol})$.
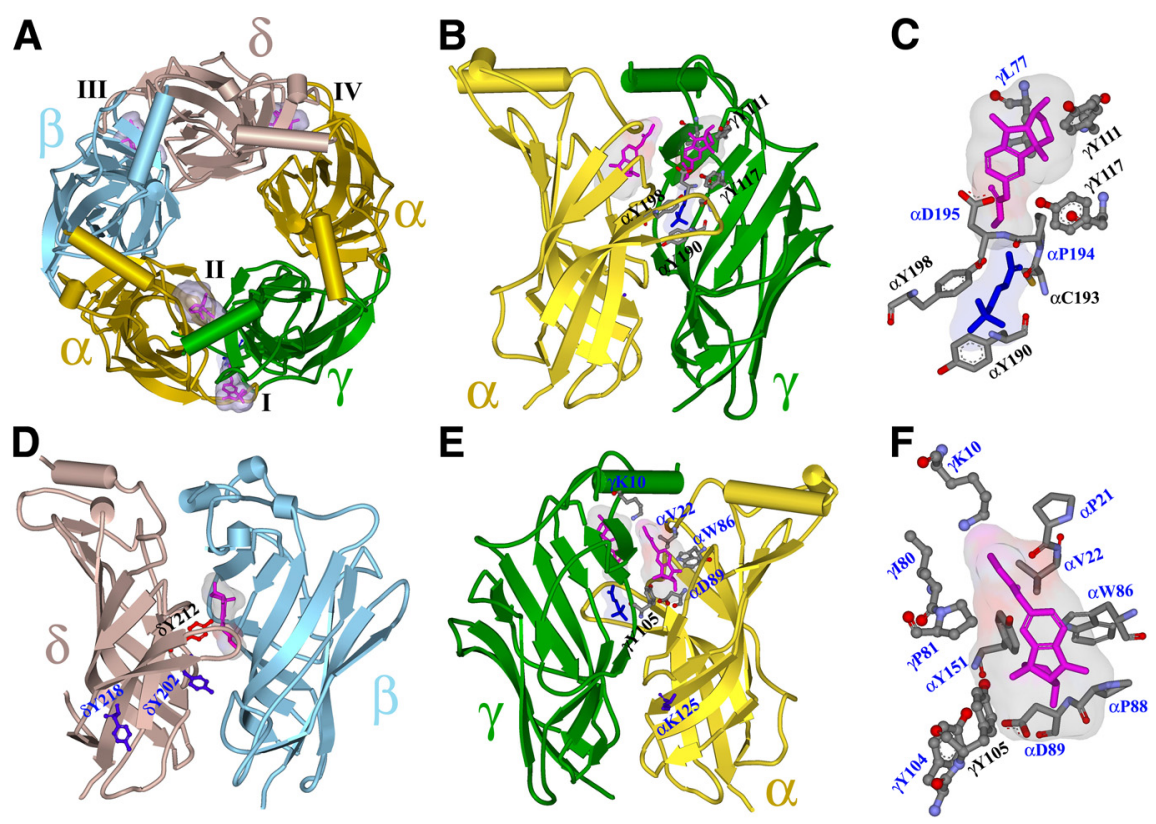

Figure 7. The binding sites for physostigmine in the $n A C h R$ extracellular domain. $\boldsymbol{A}-\boldsymbol{F}, A$ view from the top $(\boldsymbol{A})$ and side views from the exterior $(\boldsymbol{B}-\boldsymbol{D})$ and from the inside of the channel vestibule $(\boldsymbol{E}, \boldsymbol{F})$ of the extracellular domain of the Torpedo nAChR $(\alpha$, gold; $\beta$, cyan; $\gamma$, green; and $\delta$, brown) from a homology model based on the $x$-ray structure of the $L$-AChBP in the presence of Carb (PDB\#1UV6 (Celie et al., 2004)). Physostigmine is shown in stick format (magenta, volume, $197 \AA^{3}$ ) bound in its lowest energy orientation in four sites, with Connolly surface representations of the ensembles of the 30 lowest energy-docking orientations: in the presence of Carb at the $\alpha$ - $\gamma$ interface at Site I on the outer surface of the nAChR at the entry to the transmitter binding site ( $\boldsymbol{B}$; expanded in $\boldsymbol{C}$; volume, $280 \AA^{3}$ ) and at Site II in the vestibule of the ion channel (E; expanded in $\boldsymbol{F}$; volume, $\left.390 \AA^{3}\right)$, and in the absence of Carb at Site III at the $\delta$ - $\beta$ subunit interface $\left(\boldsymbol{D}\right.$, volume, $\left.270 \AA^{3}\right)$ and at the $\alpha$ - $\delta$ interface in the transmitter binding site (Site IV) $\left(\boldsymbol{A}\right.$, volume, $\left.250 \AA^{3}\right)$. In the absence of Carb, physostigmine is also predicted to bind in the transmitter binding site at the $\alpha$ - $\gamma$ interface equivalent to Site IV (data not shown). Binding to Site IV is identified by the photolabeling of $\alpha$ Tyr-93, $\alpha$ Tyr-190, and $\alpha$ Tyr-198 that is inhibited by $>90 \%$ in the presence of Carb or $\alpha$-BgTx. Carb bound at the $\alpha$ - $\gamma$ transmitter binding site is included in stick format $(\boldsymbol{B}, \boldsymbol{C}, \boldsymbol{E}$; blue). Amino acids predicted to contribute to each binding site are shown in stick format colored by elements, except in $\boldsymbol{D}$ where $\delta$ Tyr-212 is highlighted in red to contrast with the nonphotolabeled $\delta$ Tyr- 202 and $\delta$ Tyr-218 (in blue). The amino acids photolabeled in this study are identified in black by single letter code and subunit position. $\alpha$ Lys-125, which was previously reported to be photolabeled by [ ${ }^{3} \mathrm{H}$ ]physostigmine (Schrattenholz et al., 1993; Luttmann et al., 2009), is shown in blue (E). extracellular domain at two distinct sites at the canonical $\alpha-\gamma$ interface (Sites I and II) and to a site at the noncanonical $\delta$ - $\beta$ interface (Site III) in a position equivalent to the benzodiazepine binding site in $\mathrm{GABA}_{\mathrm{A}}$ receptors (Cromer et al., 2002; Richter et al., 2012). In addition, in the absence of agonist, each drug binds in the transmitter binding sites (Site IV) in proximity to the core aromatic side chains. The efficiencies of amino acid photolabeling (in $\mathrm{cpm} / \mathrm{pmol}$ ) under the different experimental conditions are summarized in Table 1. The results of computational docking studies predict other amino acids that contribute to these putative binding sites.

A binding site in the presence of agonist or $\alpha$-Bgtx on the nAChR outer surface at the entry to the transmitter binding site

At the $\alpha-\gamma$ agonist-binding interface, $\left[{ }^{3} \mathrm{H}\right]$ galanthamine and $\left[{ }^{3} \mathrm{H}\right]$ physostigmine photolabeled amino acids on the principal ( $\alpha$ Tyr-93/ $\alpha$ Tyr-190/ $\alpha$ Tyr-198/ $\alpha$ Cys-192) and complementary ( $\gamma$ Tyr$111 / \gamma$ Tyr-117) surfaces of the transmitter binding site, similar to photolabeling by agonists (Middleton and Cohen, 1991; Chiara et al., 1998; Nirthanan et al., 2005) and competitive antagonists (Chiara and Cohen, 1997; Chiara et al., 1999, 2003). However, photolabeling by agonists or competitive antagonists at both the principal and complementary surfaces was inhibited completely in the presence of excess agonist (Carb), consistent with mutually exclusive binding. In contrast, whereas $\left[{ }^{3} \mathrm{H}\right]$ physostigmine or $\left[{ }^{3} \mathrm{H}\right]$ galanthamine photolabeling of $\alpha$ subunit transmitter binding site core aromatics ( $\alpha$ Tyr-93 and $\alpha$ Tyr-190) was inhibited by $>90 \%$ in the presence of Carb or $\alpha$-BgTx, photolabeling of amino acids on the $\gamma$ complementary surface ( $\gamma$ Tyr-111/ $\gamma$ Tyr117) was inhibited by only $50-60 \%$. These results provide evidence that, in the Carb-bound or $\alpha$-BgTx-bound nAChR, physostigmine or galanthamine can still bind to a site on the complementary surface of the transmitter binding site in proximity to $\gamma$ Tyr-111/ $\gamma$ Tyr-117 (Fig. $7 B$ ).

Our computational docking analysis (see Materials and Methods) predicted that, in the presence of Carb, physostigmine binds on the outer surface of the receptor above the entry to the transmitter binding site (Fig. $7 C$ ) in a surface cavity previously identified as a potential drug binding site (Luttmann et al., 2009). In its lowest energy orientation, physostigmine is predicted to bind with its pyrolidine 
Table 1. Pharmacological specificity of $\left[{ }^{3} \mathrm{H}\right]$ physostigmine photoincorporation into residues in the Torpedo $\mathrm{AAChR}$ (cpm/pmol of PTH-amino acid) ${ }^{a}$

\begin{tabular}{|c|c|c|c|c|c|c|c|}
\hline \multirow[b]{2}{*}{ Putative site } & \multirow[b]{2}{*}{ Amino acid } & \multicolumn{2}{|c|}{ Resting state } & \multicolumn{2}{|c|}{ Resting versus desensitized } & \multicolumn{2}{|c|}{ Desensitized state } \\
\hline & & $-\alpha$-BgTx & $+\alpha$-BgTx & - Carb & + Carb & + Carb-Gal & + Carb + Gal \\
\hline \multirow[t]{2}{*}{ Site I } & $\gamma Y 111$ & 14 & 7 & 8.6 & 3.4 & 3.8 & 1.1 \\
\hline & $\gamma \mathrm{Y} 117$ & 3 & 1 & 1.8 & 0.6 & 0.7 & 0.2 \\
\hline Site II & $\gamma Y 105$ & 0.6 & 0.6 & 0.5 & 1.9 & 2.8 & 0.7 \\
\hline Site III & $\delta Y 212$ & 0.6 & 0.4 & 0.9 & 1.7 & 0.8 & 0.5 \\
\hline \multirow[t]{3}{*}{ Site IV (core aromatics) } & $\alpha \mathrm{Y} 190$ & 13 & $<0.2$ & 11 & 0.8 & ND & ND \\
\hline & $\alpha \curlyvee 198$ & 31 & 4.8 & 20.5 & 3.3 & ND & ND \\
\hline & $\alpha \curlyvee 93$ & ND & ND & 2 & $<0.2$ & ND & ND \\
\hline
\end{tabular}

ND, Not determined.

${ }^{a}$ The efficiency of photolabeling of a residue in cycle $x$ of Edman degradation (in $\mathrm{cpm} / \mathrm{pmol}$ ) was calculated from the increased release of ${ }^{3} \mathrm{H}$ cpm in cycle $x$ and the initial and repetitive yields of released PTH-amino acids. The locations in the nAChR structure of Sites I-IV are identified in Fig. 7.

$\mathrm{NCH}_{3}{ }^{+}$within $3 \AA$ of $\gamma$ Tyr-111 and $>12 \AA$ from $\alpha$ Tyr-190 or $\alpha$ Tyr-198. In contrast, in the absence of Carb (data not shown), physostigmine docked in a position overlapping the position of Carb from the AChBP structure, which positioned the pyrolidine $\mathrm{NCH}_{3}{ }^{+}$within $4 \AA$ of the hydroxyl groups of $\alpha$ Tyr-93 and $\alpha$ Tyr190/ $\alpha$ Tyr-198 (and $10 \AA$ from $\gamma$ Tyr-117).

\begin{abstract}
A binding site in the vestibule of the ion channel
$\left[{ }^{3} \mathrm{H}\right]$ Physostigmine and $\left[{ }^{3} \mathrm{H}\right]$ galanthamine also photolabeled $\gamma \mathrm{Tyr}-$ 105 (but not $\gamma$ Tyr-104), with photolabeling unchanged by $\alpha$-BgTx but increased threefold in the presence of Carb. The selective photolabeling of $\gamma \mathrm{Tyr}-105$, but not $\gamma \mathrm{Tyr}-104$, is noteworthy because in the nAChR structure both side chains are accessible from the vestibule of the ion channel (Fig. 7E, F). Because the distance between the $\gamma$ Tyr105 and $\gamma$ Tyr-111 side chains $(\sim 18 \AA)$ exceeds the length of physostigmine $(11 \AA)$, it is unlikely that $\gamma$ Tyr-105 and $\gamma$ Tyr-111 contribute to a common binding site. Rather, the photolabeling of $\gamma$ Tyr-105 provides experimental evidence of a physostigmine and galanthamine binding site in the vestibule of the ion channel in proximity to $\gamma$ Tyr- 105 .

"Blind" computational docking studies using nAChR homology models based upon the structure of AChBP predict two (Luttmann et al., 2009) or three (Iorga et al., 2006) physostigmine/galanthamine binding sites in the vestibule of the ion channel. Two sites are predicted at the $\alpha-\gamma$ interface in proximity to $\gamma$ Tyr-105, one extending above and the other below the level of $\gamma$ Tyr-105, with the third site lower in the vestibule near $\alpha$ Lys- 125 . When we used computational techniques to dock physostigmine near the $\alpha-\gamma$ transmitter binding site with bound Carb, a single site was predicted in the vestibule of the ion channel (Fig. 7E, F), with the pyrolidine $\mathrm{NCH}_{3}{ }^{+}$of physostigmine within $6 \AA$ of $\gamma$ Tyr105 and $\alpha$ Asp- 89 and the carbamate between $\gamma$ Arg-79/ $\gamma$ Pro- 81 and $\alpha$ Pro- $21 / \alpha$ Val-22 (Fig. $7 F$ ). Physostigmine access to $\gamma \mathrm{Tyr}-$ 104 is predicted to be blocked by $\gamma \mathrm{Tyr}-105$. No fragment containing $\alpha$ Tyr-151, the only other tyrosine predicted to contribute to this binding pocket, was identified in this study.
\end{abstract}

\section{A binding site at the noncanonical $\delta$ - $\boldsymbol{\beta}$ interface}

Physostigmine and galanthamine also photolabeled $\delta$ Tyr-212, located at the $\delta$ - $\beta$ interface in a position equivalent to $\alpha$ Tyr-198 (Fig. 7D), and that photolabeling was doubled in the presence of Carb. The photolabeling of $\delta$ Tyr-212 in the absence of photolabeling of $\delta$ Tyr-202 or $\delta$ Tyr-218 is significant because in the nAChR structure the latter residues have higher side chain exposure to solvent than does $\delta \mathrm{Tyr}-212$. $\left[{ }^{3} \mathrm{H}\right]$ Physostigmine photolabeling of $\beta$ subunit residues in proximity to $\delta$ Tyr-212 is not expected because there are no tyrosines on that surface. The selective photolabeling of $\delta \mathrm{Tyr}-212$ provides strong evidence that it contributes to a physostigmine/galanthamine binding pocket.
Furthermore, our computational docking predicted a most energetically favored physostigmine binding orientation with the pyrolidine $\mathrm{NCH}_{3}{ }^{+} \sim 5 \AA$ from $\delta$ Tyr-212 and $\beta$ Leu-111 (and the indole $\mathrm{NCH}_{3}{ }^{+}$within $4 \AA$ of $\delta$ Tyr-212). This binding pocket is in a position in the $\mathrm{nAChR}$ equivalent to the benzodiazepine binding site in $\mathrm{GABA}_{\mathrm{A}}$ receptors (Cromer et al., 2002; Richter et al., 2012).

A galanthamine binding site at non- $\alpha$-subunit interfaces in heteromeric $n A C h R s$ was predicted from studies of mutant AChBPs (Hansen and Taylor, 2007), and mutational analyses provide evidence for a similar positive allosteric modulator binding site in expressed $\alpha 3 \beta 2$ nAChRs for morantel (Seo et al., 2009; Cesa et al., 2012). The identification of a physostigmine binding site at the $\delta$ - $\beta$ interface raises the possibility of analogous sites at the $\beta$ - $\alpha$ or $\gamma-\alpha$ subunit interfaces. Although there are no tyrosines from the $\alpha$ subunit contributing to those interfaces, further studies are necessary to determine whether $\left[{ }^{3} \mathrm{H}\right]$ physostigmine photolabels $\beta$ Tyr-204 and/or $\gamma$ Tyr-195, which are located at positions equivalent to $\alpha$ Tyr-190 and $\alpha$ Tyr-198/ $\delta$ Tyr-212, respectively.

\section{Binding sites for $\mathrm{nAChR}$ potentiation or inhibition}

Our photolabeling studies identify three distinct nAChR binding sites for physostigmine and galanthamine in the presence of agonist, but further studies over a range of concentrations will be necessary to determine drug binding affinity at each site. Based upon their locations in $\mathrm{AAChR}$ structure, each binding site could contribute to the potentiating action of the drugs. For the homomeric $\alpha 7 \mathrm{nAChR}$, a galanthamine binding site in the presence of agonist on the outer surface of the nAChR below the level of the transmitter binding site was predicted based upon the loss of galanthamine potentiation for the $\alpha 7 \mathrm{Thr} 197 \mathrm{Ala}$ mutant nAChR (Ludwig et al., 2010). In the heteromeric muscle-type nAChR, Torpedo $\alpha$ Thr-202 or $\delta$ Thr-216 is equivalent to $\alpha 7$ Thr- 197 . $\alpha$ Thr-202 is located at the $\alpha-\gamma$ interface but distant from the photolabeled amino acids in the $\gamma$ subunit $(\sim 20 \AA$ from $\gamma$ Tyr-117 and $\sim 30 \AA$ from $\gamma$ Tyr-111) and cannot contribute directly to a binding site at the upper entry to the transmitter binding site. We would not expect physostigmine or galanthamine to photolabel Torpedo $\alpha$ Thr-202, but because $\alpha$ Tyr-203 was not photolabeled (Fig. 3A), $\alpha$ Thr-202 is unlikely to contribute directly to a physostigmine binding site. $\delta$ Thr- 216 is located at the $\delta$ - $\beta$ interface in close proximity to the photolabeled $\delta$ Tyr-212. Further studies are required to determine whether, in a muscle-type $\mathrm{nAChR}$, substitutions at $\delta \mathrm{Thr}-216$ affect galanthamine potentiation rather than substitutions at $\alpha$ Thr-202.

Mutational analyses established that $\alpha$ Asp-89, a position conserved in Cys-loop receptors, plays an important role in $\mathrm{nAChR}$ gating by interacting with $\alpha$ Thr-150 and affecting the position of $\alpha \operatorname{Trp}-149$, a core aromatic of the transmitter binding site (Lee 
and Sine, 2004; Cashin et al., 2007). Based upon our results, we predict that physostigmine binding at the site in the vestibule of the ion channel in proximity to $\gamma \mathrm{Tyr}-105$ and within $3 \AA$ of $\alpha$ Asp-89 and $\alpha$ Thr-150 (Fig. $7 F$ ) will also perturb agonist gating.

Electrophysiological assays have established that physostigmine and galanthamine have a multiplicity of effects on muscletype nAChRs: (1) direct activation at low efficacy, apparently by acting at a site distinct from the transmitter binding sites; (2) potentiation of $\mathrm{ACh}$ responses at submaximal concentrations; and (3) inhibition of ACh responses (Shaw et al., 1985; Akk and Steinbach, 2005; Texidó et al., 2005; Militante et al., 2008). Although direct binding in the ion channel may account for the inhibition by these drugs, the absence of tyrosines within the lumen of the ion channel makes $\left[{ }^{3} \mathrm{H}\right]$ physostigmine/ $\left[{ }^{3} \mathrm{H}\right]$ galanthamine photolabeling of this site unlikely. In contrast, the broad distribution of tyrosines throughout the extracellular domain of the nAChR has allowed us to directly identify by photoaffinity labeling amino acids contributing to three distinct classes of physostigmine/galanthamine binding sites, and these results provide a starting point for mutational analyses to determine the relative contributions of these different sites to the each drug's ability to directly activate the nAChR or to potentiate or inhibit ACh responses.

\section{References}

Akk G, Steinbach JH (2005) Galantamine activates muscle-type nicotinic acetylcholine receptors without binding to the acetylcholine-binding site. J Neurosci 25:1992-2001. CrossRef Medline

Arias HR (2010) Positive and negative modulation of nicotinic receptors. Adv Prot Chem Struct Biol 80:153-203. CrossRef Medline

Bertrand D, Gopalakrishnan M (2007) Allosteric modulation of nicotinic acetylcholine receptors. Biochem Pharmacol 74:1155-1163. CrossRef Medline

Blanton MP, Cohen JB (1994) Identifying the lipid-protein interface of the Torpedo nicotinic acetylcholine receptor: secondary structure implications. Biochemistry 33:2859-2872. CrossRef Medline

Brauer AW, Oman CL, Margolies MN (1984) Use of ophthalaldehyde to reduce background during automated Edman degradation. Anal Biochem 137:134-142. CrossRef Medline

Brooks BR, Brooks CL 3rd, Mackerell AD Jr, et al. (2009) CHARMM: the biomolecular simulation program. J Comp Chem 30:1545-1614. CrossRef Medline

Cashin AL, Torrice MM, McMenimen KA, Lester HA, Dougherty DA (2007) Chemical-scale studies on the role of a conserved aspartate in preorganizing the agonist binding site of the nicotinic acetylcholine receptor. Biochemistry 46:630-639. CrossRef Medline

Celie PH, van Rossum-Fikkert SE, van Dijk WJ, Brejc K, Smit AB, Sixma TK (2004) Nicotine and carbamylcholine binding to nicotinic acetylcholine receptors as studied in AChBP crystal structures. Neuron 41:907-914. CrossRef Medline

Cesa LC, Higgins CA, Sando SR, Kuo DW, Levandoski MM (2012) Specificity determinants of allosteric modulation in the neuronal nicotinic acetylcholine receptor: a fine line between inhibition and potentiation. Mol Pharmacol 81:239-249. CrossRef Medline

Chiara DC, Cohen JB (1997) Identification of amino acids contributing to high and low-affinity d-tubocurarine sites in the Torpedo nicotinic acetylcholine receptor. J Biol Chem 272:32940-32950. CrossRef Medline

Chiara DC, Middleton RE, Cohen JB (1998) Identification of tryptophan 55 as the primary site of $\left[{ }^{3} \mathrm{H}\right]$ nicotine photoincorporation in the $\gamma$-subunit of the Torpedo nicotinic acetylcholine receptor. FEBS Lett 423:223-226. Medline

Chiara DC, Xie Y, Cohen JB (1999) Structure of the agonist-binding sites of the Torpedo nicotinic acetylcholine receptor: affinity-labeling and mutational analyses identify gamma Tyr-111/ $\delta$ Arg-113 as antagonist affinity determinants. Biochemistry 38:6689-6698. CrossRef Medline

Chiara DC, Trinidad JC, Wang D, Ziebell MR, Sullivan D, Cohen JB (2003) Identification of amino acids in the nicotinic acetylcholine receptor agonist binding site and ion channel photolabeled by 4-[(3- trifluoromethyl)- ${ }^{3} \mathrm{H}$-diazirin-3-yl]benzoylcholine, a novel photoaffinity antagonist. Biochemistry 42:271-283. CrossRef Medline

Cromer BA, Morton CJ, Parker MW (2002) Anxiety over GABA A receptor structure relieved by AChBP. Trends Biochem Sci 27:280-287. Medline

Cummings JL (2004) Alzheimer's disease. N Engl J Med 351:56-67. CrossRef Medline

Czajkowski C, Kaufmann C, Karlin A (1993) Negatively charged amino acid residues in the nicotinic receptor $\delta$ subunit that contribute to the binding of acetylcholine. Proc Natl Acad Sci U S A 90:6285-6289. Medline

daCosta CJB, Free CR, Corradi J, Bouzat C, Sine SM (2011) Single-channel and structural foundations of neuronal $\alpha 7$ acetylcholine receptor potentiation. J Neurosci 31:13870-13879. CrossRef Medline

Faghih R, Briggs CA, Gopalakrishnan M (2008) Allosteric modulators of the $\alpha 7$ nicotinic acetylcholine receptor. J Med Chem 51:701-712. CrossRef Medline

Garcia G 3rd, Chiara DC, Nirthanan S, Hamouda AK, Stewart DS, Cohen JB (2007) $\left[{ }^{3} \mathrm{H}\right]$ Benzophenone photolabeling identifies state-dependent changes in nicotinic acetylcholine receptor structure. Biochemistry 46 : 10296-10307. CrossRef Medline

Geerts H, Guillaumat PO, Grantham C, Bode W, Anciaux K, Sachak S (2005) Brain levels and acetylcholinesterase inhibition with galantamine and donepezil in rats, mice, and rabbits. Brain Res 1033:186-193. CrossRef Medline

Hamouda AK, Stewart DS, Husain SS, Cohen JB (2011) Multiple transmembrane binding Sites for p-trifluoromethyldiazirinyl-etomidate, a photoreactive Torpedo nicotinic acetylcholine receptor allosteric inhibitor. J Biol Chem 286:20466-20477. CrossRef Medline

Hansen SB, Taylor P (2007) Galanthamine and non-competitive inhibitor binding to ACh-binding protein: evidence for a binding site on non- $\alpha$ subunit interfaces of heteromeric neuronal nicotinic receptors. J Mol Biol 369:895-901. CrossRef Medline

Hansen SB, Sulzenbacher G, Huxford T, Marchot P, Taylor P, Bourne Y (2005) Structures of Aplysia AChBP complexes with nicotinic agonists and antagonists reveal distinctive binding interfaces and conformations. EMBO J 24:3635-3646. CrossRef Medline

Iorga B, Herlem D, Barré E, Guillou C (2006) Acetylcholine nicotinic receptors: finding the putative binding site of allosteric modulators using the "blind docking" approach. J Mol Model 12:366-372. CrossRef Medline

Lee WY, Sine SM (2004) Invariant aspartic acid in muscle nicotinic receptor contributes selectively to the kinetics of agonist binding. J Gen Physiol 124:555-567. CrossRef Medline

Ludwig J, Höffle-Maas A, Samochocki M, Luttmann E, Albuquerque EX, Fels G, Maelicke A (2010) Localization by site-directed mutagenesis of a galantamine binding site on alpha 7 nicotinic acetylcholine receptor extracellular domain. J Recept Signal Transduct Res 30:469-483. CrossRef Medline

Luttmann E, Ludwig J, Höffle-Maas A, Samochocki M, Maelicke A, Fels G (2009) Structural model for the binding sites of allosterically potentiating ligands on nicotinic acetylcholine receptors. ChemMedChem 4:1874-1882. CrossRef Medline

Maelicke A, Albuquerque EX (2000) Allosteric modulation of nicotinic acetylcholine receptors as a treatment strategy for Alzheimer's disease. Eur J Pharmacol 393:165-170. CrossRef Medline

Maelicke A, Coban T, Storch A, Schrattenholz A, Periera EF, Albuquerque EX (1997) Allosteric modulation of Torpedo nicotinic acetylcholine receptor channel activity by noncompetitive agonists. J Recept Signal Transduct Res 17:11-28. CrossRef Medline

Marques LA, Maada I, de Kanter FJ, Lingeman H, Irth H, Niessen WM, Giera M (2011) Stability-indicating study of the anti-Alzheimer's drug galantamine hydrobromide. J Pharm Biomed Anal 55:85-92. CrossRef Medline

Middleton RE, Cohen JB (1991) Mapping of the acetylcholine binding site of the nicotinic acetylcholine receptor: $\left[{ }^{3} \mathrm{H}\right]$-nicotine as an agonist photoaffinity label. Biochemistry 30:6987-6997. CrossRef Medline

Militante J, Ma BW, Akk G, Steinbach JH (2008) Activation and block of the adult muscle-type nicotinic receptor by physostigmine: single-channel studies. Mol Pharmacol 74:764-776. CrossRef Medline

Mourot A, Grutter T, Goeldner M, Kotzyba-Hibert F (2006) Dynamic structural investigations on the Torpedo nicotinic acetylcholine receptor by time-resolved photoaffinity labeling. Chem Biochem 7:570-583. CrossRef

Nirthanan S, Ziebell MR, Chiara DC, Hong F, Cohen JB (2005) Photolabeling 
the Torpedo nicotinic acetylcholine receptor with 4-azido-2,3,5,6-tetrafluorobenzoylcholine, a partial agonist. Biochemistry 44:13447-13456. CrossRef Medline

Nirthanan S, Garcia G 3rd, Chiara DC, Husain SS, Cohen JB (2008) Identification of binding sites in the nicotinic acetylcholine receptor for TDBzletomidate, a photoreactive positive allosteric effector. J Biol Chem 283: 22051-22062. CrossRef Medline

Okonjo KO, Kuhlmann J, Maelicke A (1991) A second pathway of activation of the Torpedo acetylcholine receptor channel. Eur J Biochem 200: 671-677. CrossRef Medline

Pereira EF, Alkondon M, Reinhardt S, Maelicke A, Peng X, Lindstrom J, Whiting P, Albuquerque EX (1994) Physostigmine and galanthamine: probes for a novel binding site on the $\alpha 4 \beta 2$ subtype of neuronal nicotinic acetylcholine receptors stably expressed in fibroblast cells. J Pharmacol Exp Ther 270:768-778. Medline

Pereira EF, Reinhardt-Maelicke S, Schrattenholz A, Maelicke A, Albuquerque EX (1993) Identification and functional characterization of a new agonist site on nicotinic acetylcholine receptors of cultured hippocampal neurons. J Pharmacol Exp Ther 265:1474-1491. Medline

Pierpoint WS (1969) o-Quinones formed in plant extracts: their reactions with amino acids and peptides. Biochem J 112:609-616. Medline

Prince RJ, Sine SM (1996) Molecular dissection of subunit interfaces in the acetylcholine receptor: identification of residues that determine agonist selectivity. J Biol Chem 271:25770-25777. CrossRef Medline

Richter L, de Graaf C, Sieghart W, Varagic Z, Mörzinger M, de Esch IJ, Ecker GF, Ernst M (2012) Diazepam-bound $\mathrm{GABA}_{\mathrm{A}}$ receptor models identify new benzodiazepine binding-site ligands. Nat Chem Biol 8:455-464. CrossRef Medline

Samochocki M, Höffle A, Fehrenbacher A, Jostock R, Ludwig J, Christner C, Radina M, Zerlin M, Ullmer C, Pereira EF, Lübbert H, Albuquerque EX, Maelicke A (2003) Galantamine is an allosterically potentiating ligand of neuronal nicotinic but not of muscarinic acetylcholine receptors. J Pharmacol Exp Ther 305:1024-1036. CrossRef Medline

Savory B, Turnbull JH (1985) Luminescence studies on physostigmine, rubreserine and adrenochrome. J Photochem 31:345-358. CrossRef

Schägger H, von Jagow G (1987) Tricine-sodium dodecyl sulfate-polyacrylamide gel electrophoresis for the separation of proteins in the range from 1-100 $\mathrm{kDa}$. Anal Biochem 166:368-379. CrossRef Medline

Schrattenholz A, Godovac-Zimmermann J, Schäfer HJ, Albuquerque EX, Maelicke A (1993) Photoaffinity labeling of Torpedo acetylcholine receptor by physostigmine. Eur J Biochem 216:671-677. CrossRef Medline
Seo S, Henry JT, Lewis AH, Wang N, Levandoski MM (2009) The positive allosteric modulator morantel binds at noncanonical subunit interfaces of neuronal nicotinic acetylcholine receptors. J Neurosci 29:8734-8742. CrossRef Medline

Shaw KP, Aracava Y, Akaike A, Daly JW, Rickett DL, Albuquerque EX (1985) The reversible cholinesterase inhibitor physostigmine has channelblocking and agonist effects on the acetylcholine receptor-ion channel complex. Mol Pharmacol 28:527-538. Medline

Sherby SM, Eldefrawi AT, Albuquerque EX, Eldefrawi ME (1985) Comparison of the actions of carbamate anticholinesterases on the nicotinic acetylcholine receptor. Mol Pharmacol 27:343-348. Medline

Taly A, Corringer PJ, Guedin D, Lestage P, Changeux JP (2009) Nicotinic receptors: allosteric transitions and therapeutic targets in the nervous system. Nat Rev Drug Discov 8:733-750. CrossRef Medline

Texidó L, Ros E, Martín-Satué M, López S, Aleu J, Marsal J, Solsona C (2005) Effect of galantamine on the human alpha 7 neuronal nicotinic acetylcholine receptor, the Torpedo nicotinic acetylcholine receptor and spontaneous cholinergic synaptic activity. Br J Pharmacol 145:672-678. CrossRef Medline

Unwin N (2005) Refined structure of the nicotinic acetylcholine receptor at $4 \AA$ resolution. J Mol Biol 346:967-989. CrossRef Medline

van Dyck CH, Newhouse P, Falk WE, Mattes JA, for the Physostigmine Study Group (2000) Extended-release physostigmine in Alzheimer disease: a multicenter, double-blind, 12-week study with dose enrichment. Arch Gen Psychiatry 57:157-164. CrossRef Medline

Vodovozova EL (2007) Photoaffinity labeling and its application in structural biology. Biochemistry 72:1-20. CrossRef Medline

Wilkinson DG, Francis PT, Schwam E, Payne-Parrish J (2004) Cholinesterase inhibitors used in the treatment of Alzheimer's disease the relationship between pharmacological effects and clinical efficacy. Drug Aging 21:453-478. Medline

Williams DK, Wang J, Papke RL (2011) Positive allosteric modulators as an approach to nicotinic acetylcholine receptor-targeted therapeutics: advantages and limitations. Biochem Pharmacol 82:915-930. CrossRef Medline

Wu G, Robertson DH, Brooks CLI, Vieth M (2003) Detailed analysis of gridbased molecular docking: a case study of CDOCKER-A CHARMm-based MD docking algorithm. J Comp Chem 24:1549-1562. CrossRef Medline

Young GT, Zwart R, Walker AS, Sher E, Millar NS (2008) Potentiation of $\alpha 7$ nicotinic acetylcholine receptors via an allosteric transmembrane site. Proc Natl Acad Sci U S A 105:14686-14691. CrossRef Medline 